\title{
Aerosol hygroscopic growth, contributing factors, and impact on haze events in a severely polluted region in northern China
}

\author{
Jun Chen ${ }^{1}$, Zhanqing $\mathrm{Li}^{2}$, Min Lv ${ }^{3}$, Yuying Wang ${ }^{1}$, Wei Wang ${ }^{1}$, Yingjie Zhang ${ }^{4}$, Haofei Wang ${ }^{5,6}$, Xing Yan $^{1}$, \\ Yele $\mathrm{Sun}^{4}$, and Maureen $\mathrm{Cribb}^{2}$ \\ ${ }^{1}$ State Key Laboratory of Remote Sensing Science, College of Global Change and Earth System Science, Beijing Normal \\ University, Beijing 100875, China \\ ${ }^{2}$ Department of Atmospheric and Oceanic Sciences and ESSIC, University of Maryland, College Park, Maryland, USA \\ ${ }^{3}$ School of Geographic Science, Nantong University, Nantong 226000, China \\ ${ }^{4}$ State Key Laboratory of Atmospheric Boundary Layer Physics and Atmospheric Chemistry, Institute of Atmospheric \\ Physics, Chinese Academy of Sciences, Beijing 100029, China \\ ${ }^{5}$ College of Resource Environment and Tourism, Capital Normal University, Beijing 100048, China \\ ${ }^{6}$ State Environment Protection Key Laboratory of Satellite Remote Sensing, Institute of Remote Sensing and Digital Earth, \\ Chinese Academy of Sciences, Beijing 100101, China
}

Correspondence: Zhanqing Li (zli@atmos.umd.edu) and Yuying Wang (wang.yuying@ mail.bnu.edu.cn)

Received: 22 July 2018 - Discussion started: 30 July 2018

Revised: 14 November 2018 - Accepted: 4 December 2018 - Published: 31 January 2019

\begin{abstract}
This study investigates the impact of the aerosol hygroscopic growth effect on haze events in Xingtai, a heavily polluted city in the central part of the North China Plain (NCP), using a large array of instruments measuring aerosol optical, physical, and chemical properties. Key instruments used and measurements made include the Raman lidar for atmospheric water vapor content and aerosol optical profiles, the PC-3016A GrayWolf six-channel handheld particle and mass meter for atmospheric total particulate matter (PM) that has diameters less than 1 and $2.5 \mu \mathrm{m}\left(\mathrm{PM}_{1}\right.$ and $\mathrm{PM}_{2.5}$, respectively), the aerosol chemical speciation monitor (ACSM) for chemical components in $\mathrm{PM}_{1}$, and the hygroscopic tandem differential mobility analyzer (H-TDMA) for aerosol hygroscopicity. The changes in $\mathrm{PM}_{1}$ and $\mathrm{PM}_{2.5}$ agreed well with that of the water vapor content due to the aerosol hygroscopic growth effect. Two cases were selected to further analyze the effects of aerosol hygroscopic growth on haze events. The lidar-estimated hygroscopic enhancement factor for the aerosol backscattering coefficient during a relatively clean period (Case I) was lower than that during a pollution event (Case II) with similar relative humidity ( $\mathrm{RH})$ levels of $80 \%-91 \%$. The Kasten model was used to fit the aerosol optical hygroscopic growth factor (GF) whose parameter $b$ differed considerably between the two cases, i.e.,
\end{abstract}

0.1000 (Case I) versus 0.9346 (Case II). The aerosol acidity value calculated from ACSM data for Case I (1.35) was less than that for Case II (1.50) due to different amounts of inorganics such as $\mathrm{NH}_{4} \mathrm{NO}_{3}, \mathrm{NH}_{4} \mathrm{HSO}_{4}$, and $\left(\mathrm{NH}_{4}\right)_{2} \mathrm{SO}_{4}$. Model results based on H-TDMA data showed that aerosol hygroscopic growth factors in each size category $(40,80,110,150$, and $200 \mathrm{~nm}$ ) at different RH levels (80\%-91\%) for Case I were lower than those for Case II. For similar ambient RH levels, the high content of nitrate facilitates the hygroscopic growth of aerosols, which may be a major factor contributing to heavy haze episodes in Xingtai.

\section{Introduction}

Aerosols, as solid or liquid particles suspended in the air, help regulate Earth's climate mainly by directly scattering or absorbing incoming radiation, or indirectly changing cloud optical and microphysical properties (IPCC, 2013). Many studies suggest that aerosols have a direct impact on human health (Araujo et al., 2008; Anenberg et al., 2010; Liao et al., 2015; Li et al., 2017). For example, exposure to fine airborne particulates is linked to increased respiratory and cardiovascular diseases (Hu et al., 2015). Atmospheric aerosols can 
also reduce visibility. Poor visibility is not only detrimental to human health but also hazardous to all means of transportation (Zhang et al., 2010, 2018).

Poor visibility is caused by the presence of atmospheric aerosols whose loading depends on both emission and meteorology. The increase in anthropogenic emissions directly affects the formation of haze, such as biomass burning, and factory and vehicle emissions (Watson, 2002; Sun et al., 2006; Q. Liu et al., 2016; Qu et al., 2018). During some major events like the 2008 Summer Olympic Games, drastic measures were taken to reduce emissions, which led to a significant improvement in air quality (Huang et al., 2014; Shi et al., 2016; Y. Wang et al., 2017). This attests to the major role of emissions in air quality. Surface solar radiation and weather such as wind conditions also affect aerosol pollution (Yang et al., 2015). It has been widely known that aerosols interact with the planetary boundary layer (PBL; Quan et al., 2013; Li et al., 2017; Qu et al., 2018; Su et al., 2018). More aerosols reduce surface solar radiation, resulting in a more stable PBL which enhances the accumulation of pollutants within the PBL. Numerous studies have highlighted that the diurnal evolution of the PBL is crucial to the formation of air pollution episodes (Tie et al., 2015; Amil et al., 2016; Kusumaningtyas and Aldrian, 2016; Li et al., 2017; Qu et al., 2018). Besides feedbacks, the stability of the PBL affects the dispersion of pollutants.

Aerosol hygroscopicity also significantly affects visibility due to the swelling of aerosols (Jeong et al., 2007; Wang et al., 2014). A number of studies have shown that aerosol hygroscopic growth can accelerate the formation and evolution of haze pollution in the North China Plain (NCP; e.g., Quan et al., 2011; Liu et al., 2013; Wang et al., 2014; Yang et al., 2015). There are many ways to measure aerosol hygroscopicity. A widely used parameter, the aerosol particle size hygroscopic growth factor (GF) is defined as the ratio of the wet particle diameter $\left(D_{\mathrm{p} \text {, wet }}\right)$ at a high relative humidity $(\mathrm{RH})$ to the corresponding dry diameter $\left(D_{\mathrm{p}, \mathrm{dry}}\right)$. The GF at a certain particle size can be detected by a hygroscopic tandem differential mobility analyzer (H-TDMA; e.g., Liu et al., 1978; Swietlicki et al., 2008; Y. Wang et al., 2017). In general, the H-TDMA system mainly consists of two differential mobility analyzer (DMA) systems and one condensation particle counter (CPC). The DMA is first used to select particles at a specific size, and the second DMA and the CPC are used to measure the size distribution of humidified particles. Another instrument known as the differential aerosol sizing and hygroscopicity spectrometer probe (DASH-SP) can also measure the GF at different RHs (Sorooshian et al., 2008). The DASH-SP couples one DMA and an optical particle size spectrometer (OPSS). The dry size-dependent particles are selected by the DMA, then exposed to different RH environments, and finally measured in the OPSS (Sorooshian et al., 2008; Rosati et al., 2015).

The aerosol optical hygroscopic enhancement factor $(f(\mathrm{RH}))$ has also been employed to investigate aerosol hy- groscopicity, which is defined as the ratio of aerosol optical properties (aerosol extinction, scattering, or backscattering coefficients) between wet and dry conditions (Kotchenruther et al., 1998). Two tandem nephelometers are used to measure $f(\mathrm{RH})$ (e.g., Covert et al., 1972; Feingold and Morley, 2003; Titos et al., 2018). One nephelometer measures the aerosol optical properties of dry ambient aerosols at $\mathrm{RH}<40 \%$, and another measures that of wet aerosols at different RHs adjusted by a humidifier placed between them (Koloutsou-Vakakis et al., 2001; Titos et al., 2018). MacKinnon (1969) was the first to find that the lidar backscattering signal is affected by environmental RHs. Later studies have demonstrated the possibility of using the lidar to observe aerosol hygroscopic growth (Tardif et al., 2002; Pahlow et al., 2006; Veselovskii et al., 2009; Di Girolamo et al., 2012; Fernández et al., 2015; Granados-Muñoz et al., 2015; Lv et al., 2017; Bedoya-Velásquez et al., 2018). Compared with tandem nephelometers, lidar technology allows for measurements under unmodified ambient atmospheric conditions without drying ambient aerosols. Actual aerosol properties are not as affected when measured this way (Lv et al., 2017; Bedoya-Velásquez et al., 2018). The lidar also provides an opportunity to study the vertical characterization of aerosol hygroscopicity. Many ground-based Raman lidar systems have been operated around the world for measuring both atmospheric water vapor and aerosol profiles at higher spatial and temporal resolutions (Leblanc et al., 2012; Froidevaux et al., 2013; Wang et al., 2015; Bedoya-Velásquez et al., 2018). These measurements are useful for examining the effects of aerosol hygroscopic growth on pollution events (e.g., Y.-F. Wang et al., 2012, 2017; Su et al., 2017). Many studies on aerosol hygroscopic growth are based on the surface measurements, but few studies have investigated the vertical characterization of aerosol hygroscopicity.

Xingtai as a city with a high density of heavy industries was ranked as one of the most polluted cities in the central NCP. A joint field campaign was carried out in this region in the summer of 2016. Some studies based on this campaign have been done for understanding the causes and evolution of pollution events in this region (Y. Wang et al., 2018; Zhang et al., 2018). These studies have shown that aerosols in Xintai are highly aged and internally mixed due to strong secondary formation. The goal of this study is to further investigate how aerosol hygroscopic growth affects haze events and what are the controlling factors by combining surface and vertical measurements of aerosol optical, physical, and chemical properties.

The following section describes the instruments and methodology. Section 3 presents the results and discussion. Section 4 provides a brief summary of the study. 


\section{Instruments and methodology}

\subsection{Instruments}

A Raman lidar was used (i) to analyze the relationship between atmospheric water vapor content and $\mathrm{PM}_{1}$ or $\mathrm{PM}_{2.5}$ mass concentrations and (ii) to explore the atmospheric aerosol hygroscopic growth effect on haze events. The lidar is an automated system that retrieves atmospheric water vapor mixing ratios $(W)$ and aerosol optical property profiles (aerosol extinction and backscattering coefficients; Ångström exponent, AE; and the depolarization ratio) throughout the day. The system employs a pulsed neodymium-doped yttrium aluminum garnet laser as a light source and emits three laser beams simultaneously at 355, 532 , and $1064 \mathrm{~nm}$ with a time resolution of $15 \mathrm{~min}$ and a range resolution of $7.5 \mathrm{~m}$ based on its original factory settings. The lidar sends 5000 laser beams in the first $4 \mathrm{~min}$ and $10 \mathrm{~s}$ of the $15 \mathrm{~min}$ cycle, then the mean value of the received 5000 signals are stored as the signal profile to enhance the signal-to-noise ratio. When a laser beam is sent into the atmosphere, the received backscattering signal generally includes Mie scattering by aerosols, Rayleigh scattering by atmospheric molecules, and Raman scattering caused by the rotation and vibration of the molecules. The size of many molecules and atoms in the atmosphere is typically much smaller than the wavelength of the laser, so Rayleigh scattering occurs when they interact (Strutt, 1871). Mie scattering describes the interaction between large particles (mainly atmospheric aerosols) and laser beams. As for the optical receiving unit of this lidar system, optical fiber (OF), dichroic beam splitter (DBS), and ultra-narrowband filters following an ultraviolet telescope divide atmospheric Mie-scattering signals and vibrational Raman-scattering signals from $\mathrm{H}_{2} \mathrm{O}$ and $\mathrm{N}_{2}$ molecules (at 355,386 , and $407 \mathrm{~nm}$, respectively). Atmospheric Mie-scattering signals at 532 and $1064 \mathrm{~nm}$ are divided by OF, DBS, and ultra-narrowband filters after a visible infrared telescope. Based on the perpendicular and parallel components at $532 \mathrm{~nm}$ received by the lidar system, the aerosol depolarization ratio, a parameter that measures the shapes of aerosols, can be calculated. In general, the more irregular the particle shape, the larger the value of the depolarization ratio (Chen et al., 2002; Baars et al., 2016). The AE can also be calculated using lidar signals at 532 and $1064 \mathrm{~nm}$, which is inversely related to the average size of the aerosols (Ångström, 1964; Tiwari et al., 2016).

Co-located radiosondes were launched twice a day, i.e., at $\sim$ 07:15 and $\sim$ 19:15 China Standard Time (CST), during the field campaign. The GTS1 detector collected profiles of atmospheric $\mathrm{RH}$, temperature, and pressure at a resolution of $1.0 \%, 0.1{ }^{\circ} \mathrm{C}$, and $0.1 \mathrm{hPa}$, respectively. The radiosonde ascension velocity was typically $\sim 5-6 \mathrm{~m} \mathrm{~s}^{-1}$.

A co-located Doppler lidar system (TWP3-M) was also in operation at Xingtai. This system emits electromagnetic beams in different directions to the upper air, then directly receives the backscattering signals after those beams interact with atmospheric turbulence. Based on the Doppler effect, this system can derive time series of horizontal wind velocity and direction at a time resolution of $5 \mathrm{~min}$ and a range resolution of $60 \mathrm{~m}$ below $1 \mathrm{~km}$ and $120 \mathrm{~m}$ above $1 \mathrm{~km}$. The root-mean-square errors (RMSEs) of the Doppler-lidarretrieved wind speed and direction are typically $\leq 1.5 \mathrm{~m} \mathrm{~s}^{-1}$ and $\leq 10^{\circ}$, respectively. The maximum and minimum detection distances of this system are 3-5 and $0.1 \mathrm{~km}$, respectively.

A GrayWolf six-channel handheld particle and mass meter (model PC-3016A) was used to directly monitor the total mass concentrations of $\mathrm{PM}_{2.5}$ and $\mathrm{PM}_{1}$ in the actual atmosphere (Yan et al., 2017). The minimum detection particle size is $0.3 \mu \mathrm{m}$, and the counting efficiency for $0.3 \mu \mathrm{m}$ particles is $50 \%$ and for particle sizes greater than $0.45 \mu \mathrm{m}$ it is $100 \%$. The non-refractory $\mathrm{PM}_{1}\left(\mathrm{NR}-\mathrm{PM}_{1}\right)$ chemical components including organics, sulfate, nitrate, ammonium, and chloride were measured in situ by an aerodyne quadrupole aerosol chemical speciation monitor (ACSM) at a time resolution of $5 \mathrm{~min}$. Detailed information about the operation of the ACSM and its application in this campaign can be found elsewhere (Zhang et al., 2018). Briefly, aerosols with vacuum aerodynamic diameters of $\sim 40-1000 \mathrm{~nm}$ are sampled into the ACSM through a $100 \mathrm{~mm}$ critical orifice mounted at the inlet of an aerodynamic lens. The particles are then directed onto a resistively heated surface $\left(\sim 600^{\circ} \mathrm{C}\right)$ where NR-PM $\mathrm{P}_{1}$ components are flash vaporized and ionized by a $70 \mathrm{eV}$ electron impact. The ions are then analyzed by a commercial quadrupole mass spectrometer. Mass spectra are the raw data collected by the ACSM, and standard analysis software offered by Aerodyne Inc. is provided to derive mass concentrations of each chemical component. In this study, the ACSM was calibrated with pure ammonium nitrate following the procedure detailed by $\mathrm{Ng}$ et al. (2011) to determine its ionization efficiency. The aerosol aerodynamic particle size was determined by an aerodynamic lens. The uncertainties of ACSM-derived quantities are insignificant (Ng et al., 2011).

The aerosol GF probability distribution function (GFPDF) at $\mathrm{RH}=85 \%$ was measured by an in situ H-TDMA. The H-TDMA system mainly consists of a Nafion dryer, a bipolar neutralizer, two DMAs, a CPC, and a Nafion humidifier. The first DMA is used to select monodispersed aerosols with a set mobility size $(40,80,110,150$, and $200 \mathrm{~nm}$ in this study) after the sample is dried and neutralized by the Nafion dryer and the bipolar neutralizer. The selected particles are then humidified when passing through a Nafion humidifier with controlled RH (85\%). The second DMA and the CPC are responsible for measuring the number size distribution of the humidified particles. Finally, the TDMA-fit algorithm is used to retrieve GF-PDF (Stolzenburg and McMurry, 2008). Uncertainties of these retrieved parameters are insignificant. More detailed descriptions about the H-TDMA system are given by Tan et al. (2013) and Y. Wang et al. (2017, 2018). All data are reported in CST in this study. 


\subsection{Methodology}

\subsubsection{Water vapor retrieval}

Using the ratio of the Raman signals of $\mathrm{H}_{2} \mathrm{O}\left(P_{\mathrm{H}}\right)$ and $\mathrm{N}_{2}$ $\left(P_{\mathrm{N}}\right), W$ is calculated as follows (Melfi, 1972; Leblanc et al., 2012; Su et al., 2017):

$W(z)=C_{W} \Delta q \frac{P_{\mathrm{H}}(z)}{P_{\mathrm{N}}(z)}$,

$\Delta q=\frac{\exp \left[-\int_{0}^{z}\left(\alpha_{\mathrm{N}}^{\mathrm{m}}+\alpha_{\mathrm{N}}^{p}\right) \mathrm{d} z\right]}{\exp \left[-\int_{0}^{z}\left(\alpha_{\mathrm{H}}^{\mathrm{m}}+\alpha_{\mathrm{H}}^{p}\right) \mathrm{d} z\right]}$

where $C_{W}$ is the Raman lidar calibration constant which can be calculated using co-located radiosonde data (Melfi, 1972; Sherlock et al., 1999). The parameters $\alpha_{\mathrm{N}}^{\mathrm{m}}$ and $\alpha_{\mathrm{H}}^{\mathrm{m}}$ are the molecular extinction coefficients at 386 and $407 \mathrm{~nm}$, respectively. These can also be calculated using temperature and pressure profiles from radiosonde measurements (Bucholtz, 1995). The parameters $\alpha_{\mathrm{N}}^{p}$ and $\alpha_{\mathrm{H}}^{p}$ are the aerosol extinction coefficients (AECs) at 386 and $407 \mathrm{~nm}$, respectively. Here, we use the Fernald method to retrieve AECs (Fernald et al., 1972; Fernald, 1984), which is an analytic solution to the following basic lidar equation for Mie scattering:

$P_{\mathrm{S}}(z)=\mathrm{ECZ}^{-2}\left[\beta_{1}(z)+\beta_{2}(z)\right] T_{1}^{2}(z) T_{2}^{2}(z)$,

where $P_{\mathrm{S}}(z)$ is the return signal; $E$ is the energy emitted by the laser; $C$ is the calibration constant of the lidar system; and $\beta_{1}(z)$ and $\beta_{2}(z)$ are the backscattering cross sections of atmospheric aerosols and molecules at altitude $z$, respectively. $T_{1}(z)$ and $T_{2}(z)$ are the transmittances of aerosols and air molecules at height $z$. Note that, during the daytime, the height of the retrieved $W$ profile is limited because the Raman signal is affected by radiation (Tobin et al., 2012).

We can also calculate the vertical distribution of RH based on the vertical profile of $W$ retrieved from Raman lidar measurements and the temperature and pressure profiles provided by radiosonde data. The following equations are used to retrieve the RH profile:

$\mathrm{RH}(z)=\left[\frac{e(z)}{e_{\mathrm{S}}(z)}\right] \times 100 \%$,

$e(z)=\frac{W(z) p(z)}{0.622+W(z)}$,

$e_{\mathrm{S}}(z)=6.1078 \exp \left[\frac{17.13[T(z)-273.16]}{T(z)-38}\right]$,

where $e(z)$ and $e_{\mathrm{S}}(z)$ are the vertical profiles of water vapor pressure (in $\mathrm{hPa}$ ) and saturation vapor pressure (in $\mathrm{hPa}$ ) at a certain temperature, respectively; $W(z)$ is the $W$ profile obtained from the Raman lidar; $p(z)$ is the pressure profile (in $\mathrm{hPa}$ ); and $T(z)$ is the temperature profile (in $\mathrm{K}$ ) provided by radiosonde data.

To assess the accuracy of the retrieval algorithm, Ramanlidar- and radiosonde-derived $W$ and $\mathrm{RH}$ profiles at
05:15 CST on 24 May 2016 and their differences are shown in Fig. 1. The $W$ profiles agree reasonably well with an absolute error between them less than $0.5 \mathrm{~g} \mathrm{~kg}^{-1}$. Absolute errors between Raman-lidar- and radiosonde-derived RH profiles are generally less than $5 \%$. The same inversion results for a relatively wet case on 23 May 2016 are given in Fig. 2. In general, large absolute errors tend to occur at the inflection points. Figures 1 and 2 suggest that the retrieval algorithm can produce reasonable results.

\subsubsection{Selection of aerosol hygroscopic cases and their optical properties}

How aerosol hygroscopic growth cases were chosen is described here. First, atmospheric mixing conditions were examined using radiosonde-based vertical potential temperature $(\theta)$ and $W$ profiles. Cases with near-constant values of $\theta$ and $W$ in the analyzed layer (variations less than $2{ }^{\circ} \mathrm{C}$ and $2 \mathrm{~g} \mathrm{~kg}^{-1}$, respectively) represent good atmospheric mixing conditions (Granados-Muñoz et al., 2015). Then aerosol backscattering coefficient profiles at $532 \mathrm{~nm}$ were calculated using the Fernald method (see details in Sect. 2.2.1).

A simultaneous increase in atmospheric $\mathrm{RH}$ and the aerosol backscattering coefficient is also needed, which might indicate aerosol hygroscopic growth (BedoyaVelásquez et al., 2018). Based on the above criteria, individual cases with the same ambient humidity and different pollution conditions were selected for studying the influence of aerosol hygroscopicity on haze events. Aerosol hygroscopic properties of the selected cases were investigated in terms of the hygroscopic enhancement factor for the aerosol backscattering coefficient defined as follows:

$f_{\beta}(\mathrm{RH}, \lambda)=\frac{\beta(\mathrm{RH}, \lambda)}{\beta\left(\mathrm{RH}_{\mathrm{ref}}, \lambda\right)}$,

where $\beta(\mathrm{RH}, \lambda)$ and $\beta\left(\mathrm{RH}_{\mathrm{ref}}, \lambda\right)$ represent aerosol backscattering coefficients at a certain $\mathrm{RH}$ value and at a reference RH value, respectively, at wavelength $\lambda$. In this study, we selected $\mathrm{RH}_{\text {ref }}=80 \%$, which is the lowest $\mathrm{RH}$ in the layer.

Finally, a relationship between $f_{\beta}(\mathrm{RH})$ and $\mathrm{RH}$ was established. The most commonly used equations are the singleparameter fit equation (e.g., Hänel, 1980; Kotchenruther and Hobbs, 1998; Gassó et al., 2000) and the dual-parameter fit equation (e.g., Hänel, 1980; Carrico, 2003; Zieger et al., 2011). The single-parameter fit equation introduced by Hänel (1976) is

$f_{\beta}(\mathrm{RH})=\left(\frac{1-\mathrm{RH}}{1-\mathrm{RH}_{\mathrm{ref}}}\right)^{-\gamma}$,

where $\gamma$ in an empirical parameter. Larger $\gamma$ values in this formulation denote a stronger hygroscopic growth.

The dual-parameter fit equation is (Fernández et al., 2015)

$f_{\beta}(\mathrm{RH})=a(1-\mathrm{RH})^{-\mathrm{b}}$. 

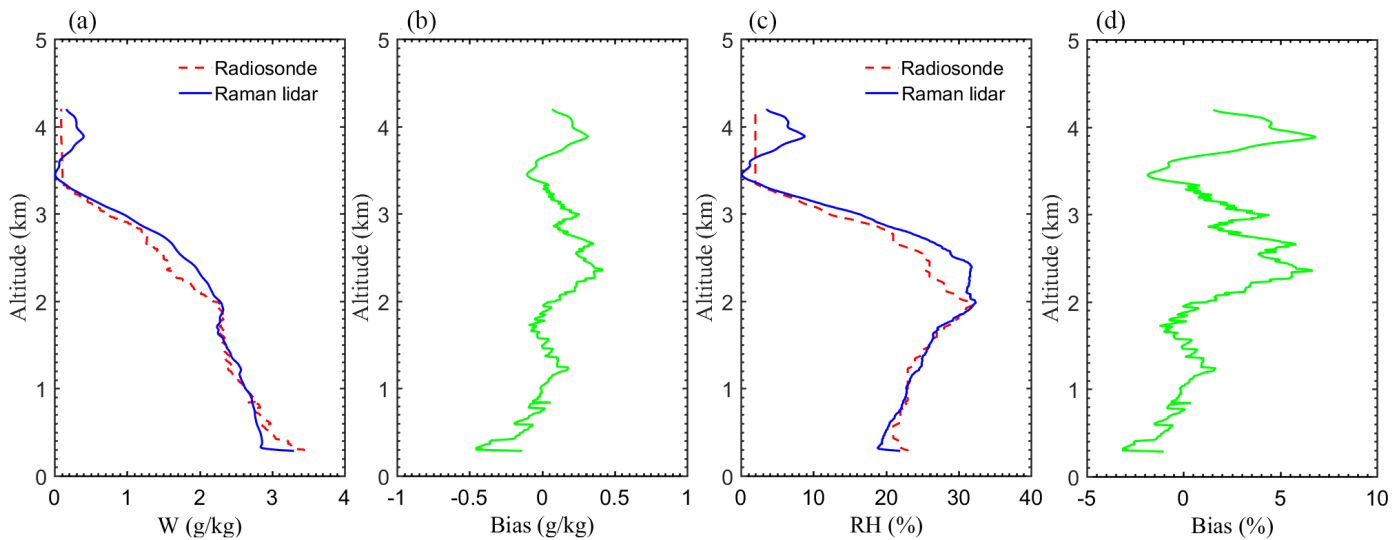

Figure 1. (a, c) Water vapor mixing ratio $(W)$ and relative humidity $(\mathrm{RH})$ profiles at 05:15 CST 24 May 2016 retrieved by the Raman lidar (blue line) and the radiosonde (red dashed line), respectively, and (b, d) the absolute error in $W$ and RH between the lidar and radiosonde retrievals (lidar minus radiosonde), respectively.
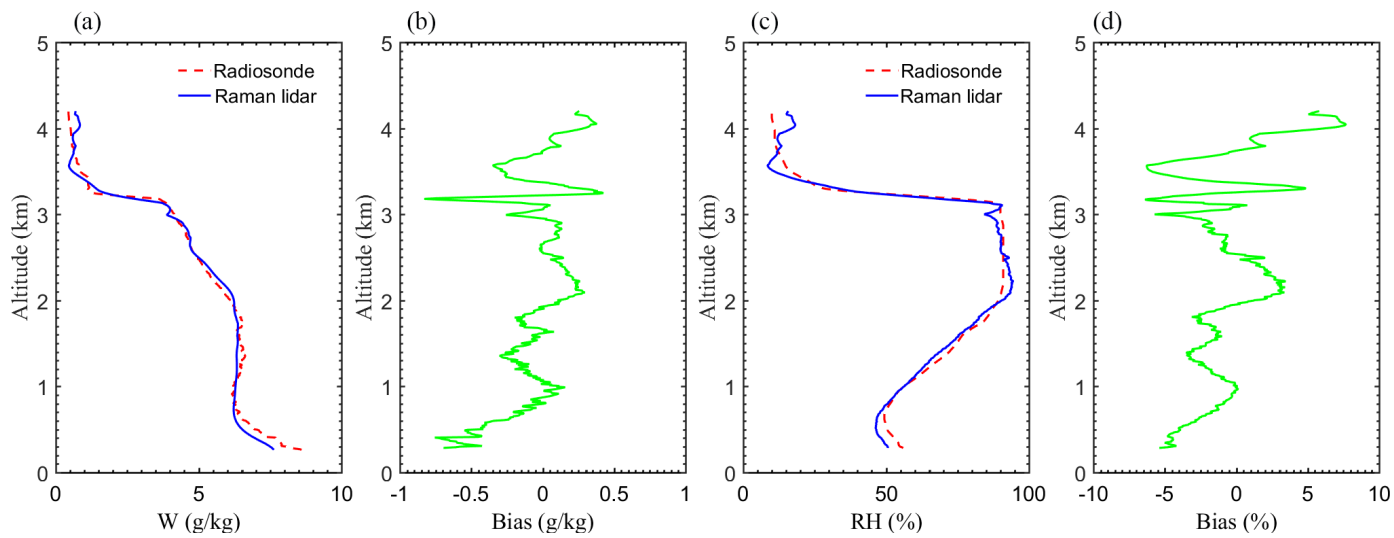

Figure 2. (a, c) Water vapor mixing ratio $(W)$ and relative humidity (RH) profiles at 20:00 CST 23 May 2016 retrieved by the Raman lidar (blue line) and the radiosonde (red dashed line), respectively, and (b, d) the absolute error in $W$ and RH between the lidar and radiosonde retrievals (lidar minus radiosonde), respectively.

The single- and dual-parameter fit equations are similar, but with an additional scale factor parameter, $a$, in the case of the dual-parameter fit equation. The parameter $b$ is also an empirical parameter with larger values of $b$ indicating particles with stronger hygroscopicities. In this study, both parameterized equations are used to verify the consistency of the results. The equation that fits the measurement data best is selected.

\subsubsection{Calculation of aerosol acidity}

Aerosol acidity is associated with aerosol hygroscopic growth (e.g., Sun et al., 2009; Fu et al., 2015; Zhang et al., 2015; Lv et al., 2017). When atmospheric aerosols are acidic, they have stronger hygroscopicities than when in their neutralized forms (Zhang et al., 2015). The swelling of aerosols due to hygroscopic growth enhances their ability to scatter solar radiation. We examined acidity by comparing the measured $\mathrm{NH}_{4}^{+}$mass concentration with the needed amount to fully neutralize sulfate, nitrate, and chloride ions $\left(\mathrm{NH}_{4}^{+}\right.$predicted $)$detected by the ACSM (Sun et al., 2009; Zhang et al., 2015; Lv et al., 2017):

$$
\begin{aligned}
\mathrm{NH}_{4}^{+} \text {predicted } & =\left(2 \times \mathrm{SO}_{4}^{2-} / 96+\mathrm{NO}_{3}^{-} / 62+\mathrm{Cl}^{-} / 35.5\right) \\
& \times 18
\end{aligned}
$$

where $\mathrm{SO}_{4}^{2-}, \mathrm{NO}_{3}^{-}$, and $\mathrm{Cl}^{-}$represent the mass concentrations (in $\mu \mathrm{g} \mathrm{m}^{-3}$ ) of the three species measured by the ACSM. The molecular weights of $\mathrm{SO}_{4}^{2-}, \mathrm{NO}_{3}^{-}, \mathrm{Cl}^{-}$, and $\mathrm{NH}_{4}^{+}$are $96,62,35.5$, and 18, respectively. Aerosols are considered "more acidic" if the measured $\mathrm{NH}_{4}^{+}$mass concentration is significantly lower than that of $\mathrm{NH}_{4}^{+}$predicted . Aerosols are considered "bulk neutralized" if the two values are similar (Zhang et al., 2007, 2015; Sun et al., 2009; Lv et al., 2017). 
The acidity of aerosols can be quantified by a parameter called the acid value (AV) (Zhang et al., 2007):

$$
\begin{aligned}
\mathrm{AV} & =\left(2 \times \mathrm{SO}_{4}^{2-} / 96+\mathrm{NO}_{3}^{-} / 62+\mathrm{Cl}^{-} / 35.5\right) \\
& /\left(\mathrm{NH}_{4}^{+} / 18\right) .
\end{aligned}
$$

The chemical formula and numbers after the equal sign have the same meanings as in Eq. (10). Aerosols are considered bulk neutralized if $\mathrm{AV}=1$ and "strongly acidic" if $\mathrm{AV}>1.25$. When $\mathrm{AV}=1.25,50 \%$ of the total sulfate ions in the atmosphere consist of $\mathrm{NH}_{4} \mathrm{HSO}_{4}$, and the other $50 \%$ consist of $\left(\mathrm{NH}_{4}\right)_{2} \mathrm{SO}_{4}$.

\subsubsection{Aerosol-chemical-ion-pairing scheme}

The magnitude of $f(\mathrm{RH})$ is correlated with the inorganic mass fraction (Zieger et al., 2014). However, GFs differ with different inorganic salts. To examine the mass fractions of neutral inorganic salts, ACSM measurements were used to calculate their mass concentrations and volume fractions (Gysel et al., 2007). This approach is based on the ionpairing scheme introduced by Reilly and Wood (1969). The ACSM mainly measures the mass concentrations of $\mathrm{SO}_{4}^{2-}$, $\mathrm{NO}_{3}^{-}, \mathrm{NH}_{4}^{+}, \mathrm{Cl}^{-}$, and organics. The chlorine ion was not considered here because its concentration is low. The aerosolchemical-ion-combination scheme is given by the following equations:

$$
\begin{aligned}
& n_{\mathrm{NH}_{4} \mathrm{NO}_{3}}=n_{\mathrm{NO}_{3}^{-}}, \\
& n_{\mathrm{NH}_{4} \mathrm{HSO}_{4}}=\min \left(2 n_{\mathrm{SO}_{4}^{2-}}-n_{\mathrm{NH}_{4}^{+}}+n_{\mathrm{NO}_{3}^{-}}, n_{\mathrm{NH}_{4}^{+}}-n_{\mathrm{NO}_{3}^{-}}\right), \\
& n_{\left(\mathrm{NH}_{4}\right)_{2} \mathrm{SO}_{4}}=\max \left(n_{\mathrm{NH}_{4}^{+}}-n_{\mathrm{NO}_{3}^{-}}-n_{\mathrm{SO}_{4}^{2-}}, 0\right) \\
& n_{\mathrm{H}_{2} \mathrm{SO}_{4}}=\max \left(0, n_{\mathrm{SO}_{4}^{2-}}-n_{\mathrm{NH}_{4}^{+}}+n_{\mathrm{NO}_{3}^{-}}\right) \\
& n_{\mathrm{HNO}_{3}}=0
\end{aligned}
$$

where $n$ donates the mole numbers, and "min" and " $m a x$ " are minimum and maximum values (Gysel et al., 2007). The volume fractions of inorganic salts can be calculated based on the ion combination scheme and the parameters in Table 1. Furthermore, for a multicomponent particle, the ZdanovskiiStokes-Robinson mixing rule (Zdanovskii, 1948; Stokes and Robinson, 1966) can be applied to calculate the hygroscopicity parameter $\kappa$ :

$\kappa=\sum_{i} \varepsilon_{i} \kappa_{i}$,

where $\kappa_{i}$ is the hygroscopicity parameter of each individual component. The parameter $\varepsilon_{i}$ is the volume fraction of each component.
Table 1. Aerosol properties of selected compounds used for the calculation of the hygroscopicity parameter $\kappa$, i.e., the density $\left(\rho_{i}\right)$ and $\left(\kappa_{i}\right)$ of each compound.

\begin{tabular}{lrrrr}
\hline Species & $\mathrm{NH}_{4} \mathrm{NO}_{3}$ & $\mathrm{NH}_{4} \mathrm{HSO}_{4}$ & $\left(\mathrm{NH}_{4}\right)_{2} \mathrm{SO}_{4}$ & $\mathrm{H}_{2} \mathrm{SO}_{4}$ \\
\hline Density & 1.725 & 1.78 & 1.76 & 1.83 \\
$\kappa^{\mathrm{b}}$ & 0.68 & 0.56 & 0.52 & 0.91 \\
\hline
\end{tabular}

a Tang and Munkelwitz (1994); Carrico et al. (2010); ${ }^{b}$ Fountoukis and Nenes (2007); Carrico et al. (2010); Liu et al. (2014).

\section{Results and discussion}

\subsection{Observations of $W$ and mass concentrations of $\mathbf{P M}_{1}$ and $\mathbf{P M}_{2.5}$}

Figure 3a shows the time series of the lidar-derived $W$ at Xingtai from 19 to 31 May 2016. The height of the retrieved $W$ profile was limited because of solar radiation during the daytime (e.g., Tobin et al., 2012). Overall, $W$ is generally less than $6 \mathrm{~g} \mathrm{~kg}^{-1}$ between 0.3 and $4 \mathrm{~km}$ with a strong daily variability during the period analyzed. Figure $3 \mathrm{~b}$ and $\mathrm{c}$ show the simultaneous time series of the surface mass concentrations of $\mathrm{PM}_{1}$ and $\mathrm{PM}_{2.5}$, and $W$ and $\mathrm{RH}$, respectively. The variabilities in $\mathrm{PM}_{1}$ and $\mathrm{PM}_{2.5}$ mass concentrations are strongly coupled with that in $W$ at the surface and in the lower atmospheric layer. Others have also found the same relationship between $W$ in the lower atmospheric layer and the surface mass concentration of $\mathrm{PM}_{2.5}$ (e.g., Y.-F. Wang et al., 2012, 2017; Su et al., 2017). Su et al. (2017) suggested that this is due to the aerosol hygroscopic growth effect. The aerosol hygroscopicity is related to aerosol chemical composition over the North China Plain (Zou et al., 2018). Figure 3d shows simultaneous mass fractions of the chemical species comprising $\mathrm{PM}_{1}$. As $W$ in the lower atmospheric layer and the surface mass concentrations of $\mathrm{PM}_{1}$ and $\mathrm{PM}_{2.5}$ increases, the proportion of organic aerosols decreases (highlighted as shaded grey areas in Fig. 3), suggesting that the proportion of hygroscopic aerosols increased. This shows that strong aerosol hygroscopicity may aggravate air pollution conditions over Xingtai.

Two instances when this relationship was not seen (highlighted as shaded grey areas in Fig. 3) are shown by the black triangles in Fig. 3d and marked with grey lines across Fig. 3. In the evening of 21 May 2016 (the leftmost triangle and grey line), $W$ and the mass fractions of organics are comparable to those in the evening of 23 May (the rightmost triangle and grey line in Fig. 3). However, the mass concentrations of $\mathrm{PM}_{1}$ and $\mathrm{PM}_{2.5}$ at that time indicated by the leftmost grey line (in the evening of 21 May 2016) are significantly less than that in the evening of 23 May (indicated by the rightmost grey line). Su et al. (2017) and Y.-F. Wang et al. $(2012,2017)$ have studied the relationship between atmospheric water vapor and haze events over Beijing and Xi' an, respectively, using Raman lidar measurements. Their analyses showed a positive 


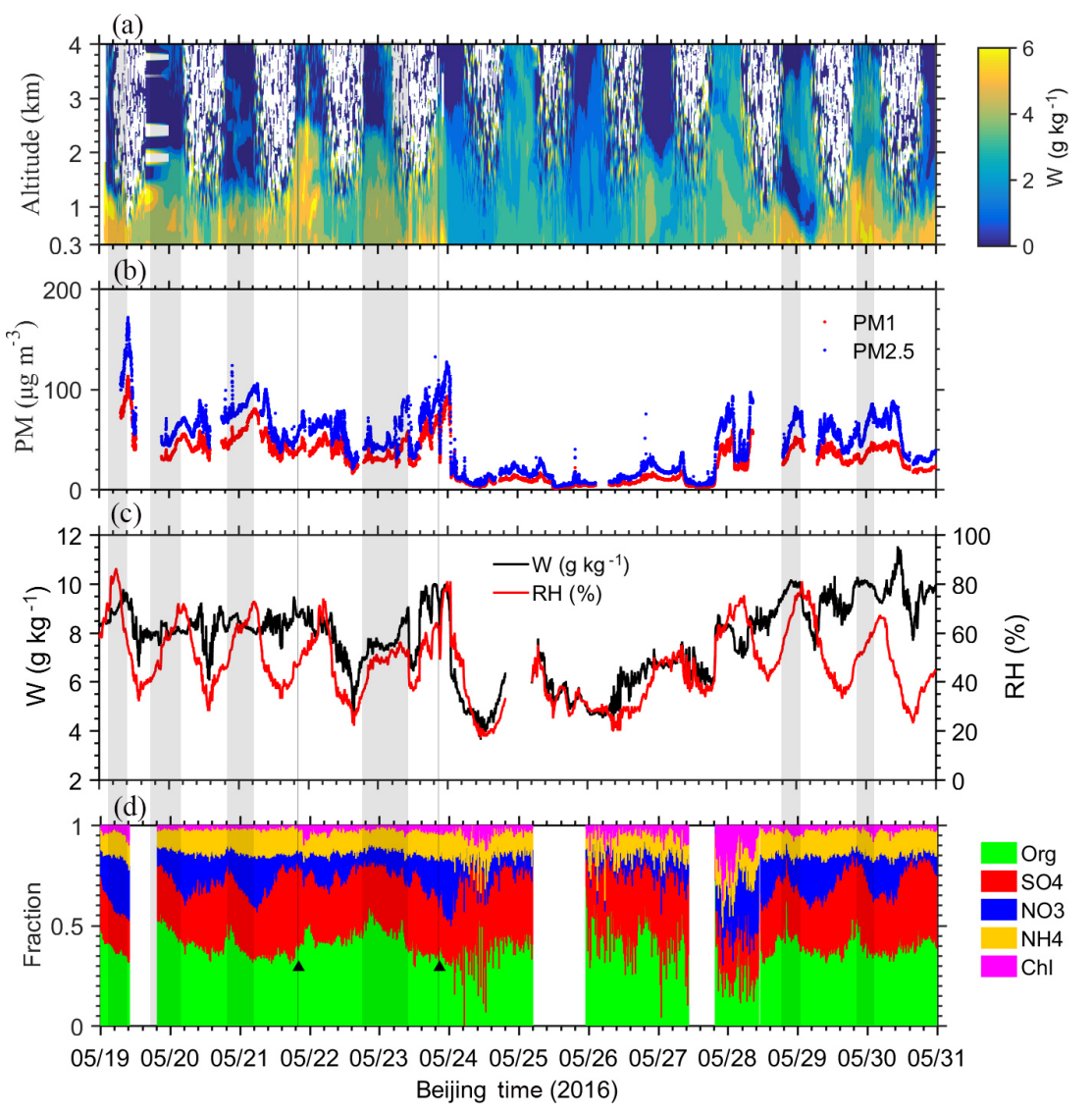

Figure 3. Time series of (a) water vapor mixing ratio $(W)$ profiles measured by the Raman lidar, (b) mass concentrations of $\mathrm{PM}_{1}$ (red dots) and $\mathrm{PM}_{2.5}$ (blue dots), (c) surface $W$ (black line) and relative humidity (RH, red line), and (d) chemical species mass fractions of $\mathrm{PM}_{1}$ measured by the ACSM. Data are from 19 to 31 May 2016 at Xingtai. The shaded grey areas are to enhance the readability of the article. The black triangles in (d) and grey lines in (a)-(d) represent the two cases chosen for further examination. Blank parts of the data are missing due to uncontrollable factors such as power supply.

correlation between $W$ and $\mathrm{PM}_{10}$ and $\mathrm{PM}_{2.5}$ mass concentrations, but they ignored some unexpected cases behind this positive correlation. The two unexpected cases that occurred on 21 May 2016 (Case I) and 23 May 2016 (Case II) were selected for further study.

\subsection{Cases studies of aerosol hygroscopic growth}

\subsubsection{Lidar-estimated hygroscopic measurements}

Two cases were selected: one on 21 May 2016 (Case I) and the other on 23 May 2016 (Case II) at the closest time of the radiosonde launch time at 19:15CST. Figure 5 shows the vertical distributions of $W, \theta$, the aerosol backscattering coefficient at $532 \mathrm{~nm}\left(\beta_{532}\right)$, the backscatter-related Ångström exponent based on measurements at 532 and $1064 \mathrm{~nm}$, and the particle linear depolarization ratio at $532 \mathrm{~nm}$ for Case I and Case II. The altitude ranges are $1642.5-1905.5 \mathrm{~m}$ for Case I and $1680.0-2130.0 \mathrm{~m}$ for Case II. $W$ and $\theta$ calculated from radiosonde-measured temperature and $\mathrm{RH}$ profiles were used to examine the atmospheric mixing conditions in the individ- ual layers. Table 2 lists the gradients of the variables within each layer. The gradient in $W$ changes little within the layer of interest, decreasing monotonically with altitude at a rate of -0.34 and $-1.42 \mathrm{~g} \mathrm{~kg}^{-1} \mathrm{~km}^{-1}$ for Case I and Case II, respectively. The gradient in $\theta$ shows a monotonic increase within the layers of interest $\left(0.27^{\circ} \mathrm{C} \mathrm{km}^{-1}\right.$ for Case I and $0.96^{\circ} \mathrm{C} \mathrm{km}^{-1}$ for Case II). Overall, $W$ and $\theta$ variations are less than $2 \mathrm{~g} \mathrm{~kg}^{-1}$ and $2{ }^{\circ} \mathrm{C}$, respectively, showing that good mixing atmospheric conditions were present in both cases (Granados-Muñoz et al., 2015). This confirms that aerosols within the analyzed layer of each case were well mixed.

Figure 4 shows the time series of the horizontal wind velocity and direction retrieved from the co-located Doppler lidar system. From 18:30 to 20:30 CST, Case I (Fig. 4c) and Case II (Fig. 4d) winds within their respective layers are mainly from the north and northwest, respectively, and have relatively low speeds $\left(<5 \mathrm{~m} \mathrm{~s}^{-1}\right.$, Fig. $4 \mathrm{a}$ and b). This suggests that the aerosols in each case were transported into their respective layers at low speeds from almost the same direction. 
Table 2. Range of values and gradient values over the analyzed layer for the water vapor mixing ratio $(W)$, the potential temperature $(\theta)$, the backscattering coefficient at $532 \mathrm{~nm}\left(\beta_{532}\right)$, the Ångström exponent (AE, $(532-1064 \mathrm{~nm})$ ), and the depolarization ratio at $532 \mathrm{~nm}$ for Case I and II.

\begin{tabular}{lrrr|rrr}
\hline & \multicolumn{3}{c|}{ Case I } & \multicolumn{3}{c}{ Case II } \\
\cline { 2 - 7 } & \multicolumn{2}{c}{ Range } & $\begin{array}{r}\text { Gradient } \\
\left(\mathrm{km}^{-1}\right)\end{array}$ & Range & $\begin{array}{r}\text { Gradient } \\
\left(\mathrm{km}^{-1}\right)\end{array}$ \\
\hline Altitude $(\mathrm{m})$ & 1642.5 & 1905.0 & - & 1680.0 & 2130.0 & - \\
$W\left(\mathrm{~g} \mathrm{~kg}^{-1}\right)$ & 7.65 & 7.56 & -0.34 & 6.42 & 5.78 & -1.42 \\
$\theta\left({ }^{\circ} \mathrm{C}\right)$ & 26.93 & 27.00 & 0.27 & 25.18 & 25.61 & 0.96 \\
$\mathrm{RH}(\%)$ & 80 & 91 & - & 80 & 91 & - \\
$\beta_{532 \mathrm{~nm}\left(\mathrm{~km}^{-1} \mathrm{sr}^{-1}\right)}$ & 0.01379 & 0.01535 & - & 0.003711 & 0.006762 & - \\
AE $\left(532-1064 \mathrm{~nm}^{2}\right.$ & 0.74 & 0.68 & -0.23 & 0.42 & 0.35 & -0.16 \\
Depolarization ratio & 0.046 & 0.044 & -0.0076 & 0.041 & 0.039 & -0.0044 \\
\hline
\end{tabular}
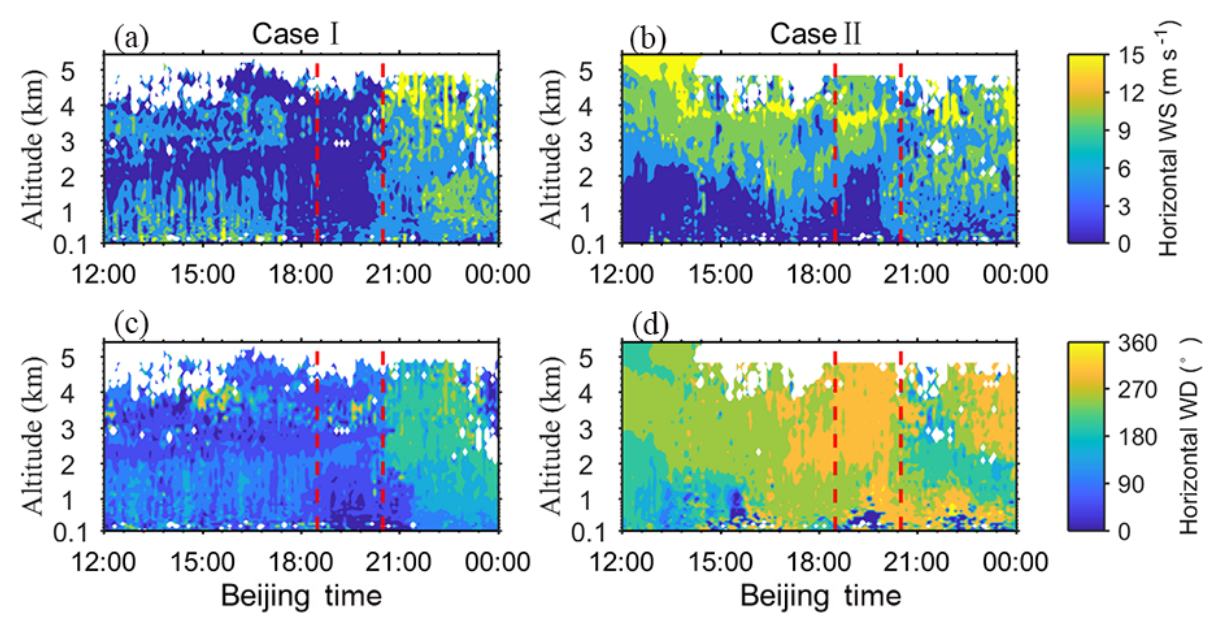

Figure 4. Time series of Doppler-lidar-retrieved (a, b) horizontal wind speed and (c, d) horizontal wind direction on 21 May 2016 (Case I, left-hand panels) and 23 May 2016 (Case II, right-hand panels). Red dashed lines outline the time range 18:30-20:30 CST. The analyzed layers are 1642.5-1905.0 $\mathrm{m}$ for Case I and 1680.0-2130.0 $\mathrm{m}$ for Case II.

In other words, there is no change in the aerosol type of both cases within the region of interest.

The RH and $\beta_{532}$ simultaneously increase with altitude in the Case I (Fig. 5c and d) and Case II (Fig. 5i and j) layers of interest. The AE and depolarization ratio were retrieved in order to differentiate the fine and coarse mode predominance and shape of the aerosols (Fig. 5e, f, k, and 1). A decrease in $\mathrm{AE}$ and the depolarization ratio suggests that there is an increase in the predominance of coarse-mode particles and an increase in the sphericity of particles due to water uptake, respectively (Granados-Muñoz et al., 2015; Lv et al,. 2017; Bedoya-Velásquez et al., 2018).

Based on the $\beta_{532}$ and $\mathrm{RH}$ profiles retrieved from Raman lidar measurements, the enhancement factor for the backscattering coefficient at $532 \mathrm{~nm}, f_{\beta}(\mathrm{RH})$, is calculated for both cases using Eq. (7). The reference $\mathrm{RH}$ value was set to $80 \%$ in this study, the lowest $\mathrm{RH}$ recorded in the layers of interest of both cases. This study applies the single-parameter Hänel model (Eq. 8) and the dual-parameter Kasten model
(Eq. 9). Table 3 lists the parameterized results of each model for each case, and Fig. 6 shows the best-fit lines. The $f_{\beta}(\mathrm{RH})$ for Case II is greater than that for Case I. $\beta_{532}$ increases by a factor of 1.094 (Case I) and 1.794 (Case II) as RH changes from $80 \%$ to $91 \%$. The magnitudes of $f_{\beta}(85 \%)$ for Case I and Case II are 1.0283 and 1.0770, respectively. The $b$ value from the Kasten parameterization is much larger in Case II (0.9346) than in Case I (0.1000), and the $\gamma$ value from Hänel parameterization for Case II (0.6538) is also much larger than that for Case I (0.09895). Chen et al. (2014) studied the aerosol hygroscopicity parameter derived from lightscattering enhancement factor $(f(\mathrm{RH}))$ measurements made in the NCP and showed that $f(\mathrm{RH})$ for polluted cases is higher than that for clean periods at a specific RH. This is consistent with the results of this study where the mass concentrations of $\mathrm{PM}_{1}$ and $\mathrm{PM}_{2.5}$ during Case II $\left(69.36 \mu \mathrm{g} \mathrm{m}^{-3}\right.$ for $\mathrm{PM}_{1}$ and $94.88 \mu \mathrm{g} \mathrm{m}^{-3}$ for $\mathrm{PM}_{2.5}$ ) were greater than those during Case I $\left(34.08 \mu \mathrm{g} \mathrm{m}^{-3}\right.$ for $\mathrm{PM}_{1}$ and $45.00 \mu \mathrm{g} \mathrm{m}^{-3}$ for $\mathrm{PM}_{2.5}$ ). An observational study of the influence of aerosol 
(a)

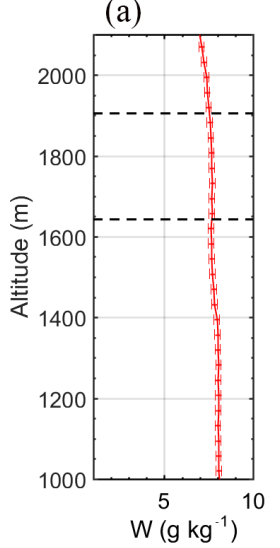

$(\mathrm{g})$

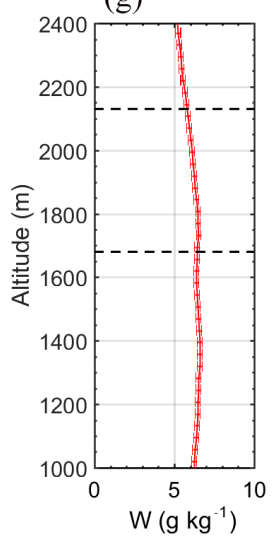

(b)

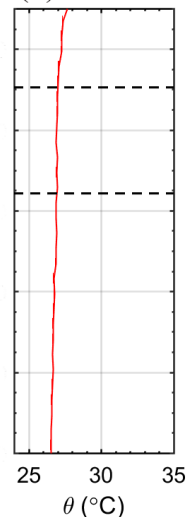

(h)

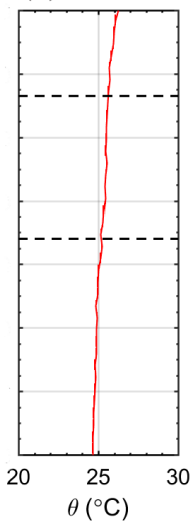

Case I

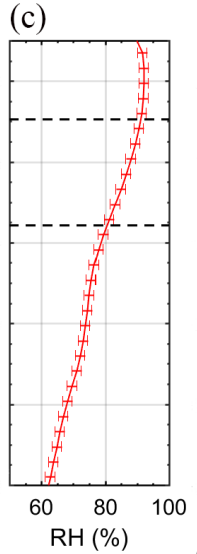

(d)

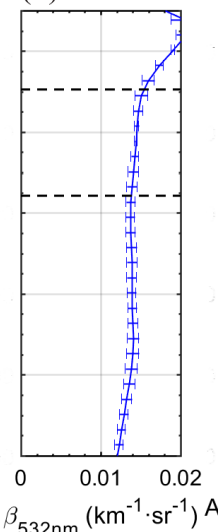

(e)

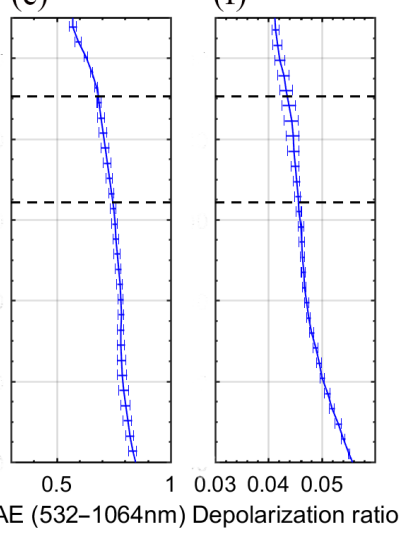

Case II

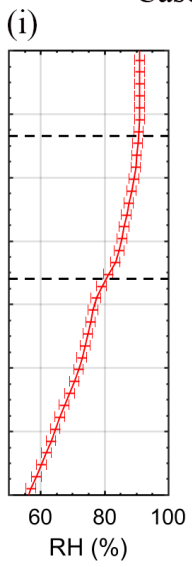

(j) $\quad(\mathrm{k})$

(l)

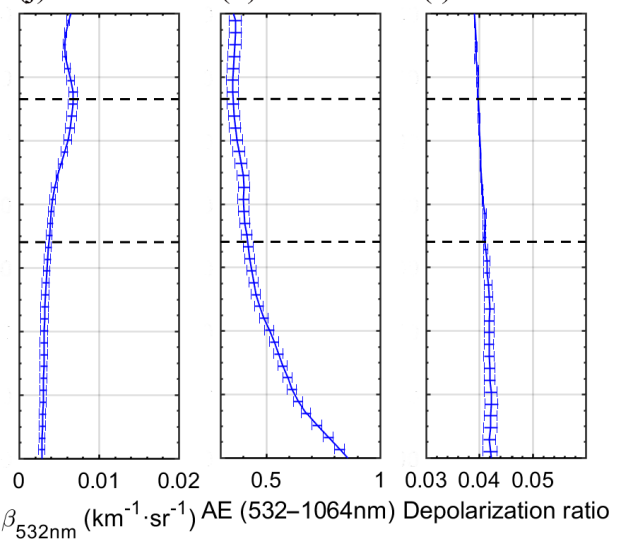

Figure 5. The vertical profiles of (a, g) water vapor mixing ratio $(W),(\mathbf{b}, \mathbf{h})$ potential temperature $(\theta),(\mathbf{c}, \mathbf{i})$ relative humidity $(\mathrm{RH})$ calculated from radiosonde data, $(\mathbf{d}, \mathbf{j})$ backscattering coefficient at $532 \mathrm{~nm}\left(\beta_{532}\right),(\mathbf{e}, \mathbf{k})$ the Ångström exponent (AE, $\left.(532-1064 \mathrm{~nm})\right)$, and (f, l) depolarization ratio retrieved from Raman lidar data for Case I (a-f) and Case II (g-l). Horizontal dashed lines show the upper and lower boundaries of the layer under analysis $(1642.5-1905.0 \mathrm{~m}$ for Case I and $1680.0-2130.0 \mathrm{~m}$ for Case II). Horizontal error bars denote the uncertainty of each property.

Table 3. The fitting parameters and $R^{2}$ of the fits for the Kasten and Hänel models.

\begin{tabular}{crrr|rrr}
\hline & \multicolumn{3}{c}{ Case I } & \multicolumn{3}{c}{ Case II } \\
\cline { 2 - 7 } Kasten model & $a$ & $b$ & $R^{2}$ & $a$ & $b$ & $R^{2}$ \\
\cline { 2 - 7 } & 0.8508 & 0.1000 & 0.97 & 0.1916 & 0.9346 & 0.95 \\
\hline \multirow{3}{*}{ Hänel model } & \multicolumn{2}{c}{$\gamma$} & $R^{2}$ & \multicolumn{2}{|c}{$\gamma$} & $R^{2}$ \\
\cline { 2 - 6 } & $0.09895 \pm 0.0047$ & 0.97 & $0.6538 \pm 0.0662$ & 0.84 \\
\hline
\end{tabular}

hygroscopic growth on the scattering coefficient at a rural area near Beijing also demonstrated that aerosols had relatively strong water-absorbing properties during urban pollution periods (Pan et al., 2009).

\subsubsection{The influences of chemical composition inferred from ACSM measurements}

Liu et al. (2014) have pointed out that inorganics are the primary aerosol component contributing to aerosol hygroscopicity especially in the size range of $150-1000 \mathrm{~nm}$. The acidity of aerosols is a key parameter affecting aerosol hygroscopic growth (Sun et al., 2009; Lv et al., 2017). The dominant form 


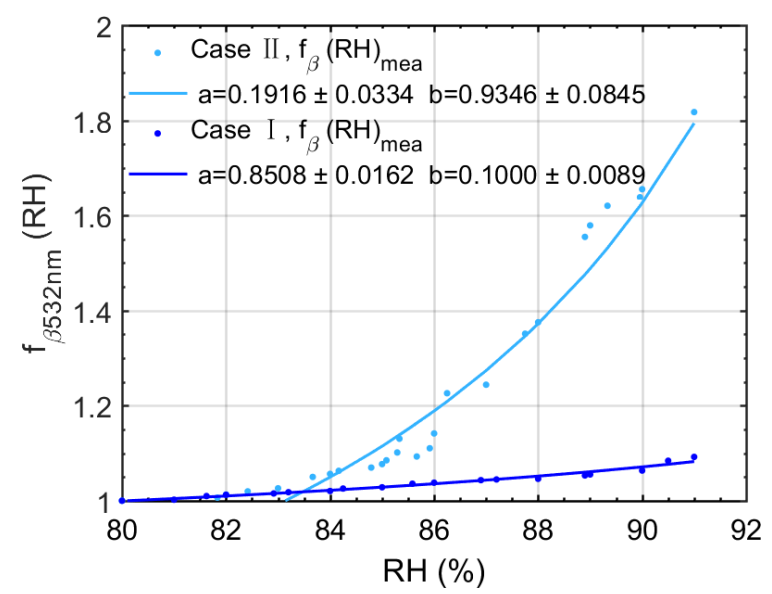

Figure 6. $f_{\beta}(\mathrm{RH})$ at $532 \mathrm{~nm}$ retrieved on 21 May 2016 in the 1642.5-1905.0 m layer (Case I, dark blue points) and 23 May 2016 in the 1680.0-2130.0 m layer (Case II, light blue points). The bestfit lines through the points are shown. The reference $\mathrm{RH}$ is $80 \%$.

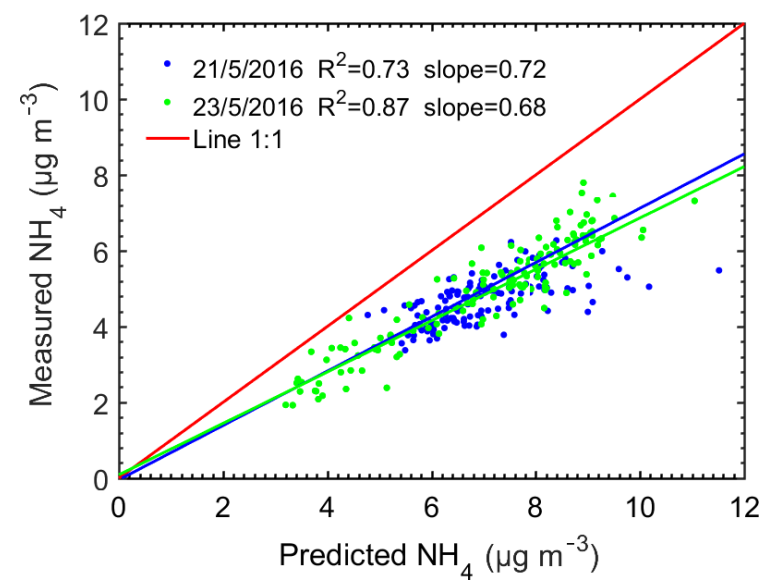

Figure 7. Mass concentrations of measured ammonium $\left(\mathrm{NH}_{4}\right)$ versus predicted ammonium assuming full neutralization of sulfate, nitrate, and chloride on the whole day of 21 May 2016 (blue dots, Case I) and 23 May 2016 (green dots, Case II). The solid blue and green lines are the least-squares regression lines for each day. The $1: 1$ line is shown in red.

of inorganics can be examined by comparing measured $\mathrm{NH}_{4}^{+}$ and predicted $\mathrm{NH}_{4}^{+}$( $\mathrm{Lv}$ et al., 2017; see Sect. 2.2.3 for details).

Figure 7 shows the relationships between ACSMmeasured $\mathrm{NH}_{4}^{+}$and predicted $\mathrm{NH}_{4}^{+}$based on $\mathrm{PM}_{1}$ chemical species information collected during the full day of each case. The slopes of the linear regression best-fit lines are 0.72 and 0.68 on 21 (Case I) and 23 May 2016 (Case II), respectively. The RMSEs of the linear regression best-fit lines are 0.63 and 0.48 on 21 and 23 May 2016, respectively. The parameter AV for Case I is 1.35 and the parameter AV for Case II is 1.50 . These values suggest that there was insufficient $\mathrm{NH}_{3}$ in the atmosphere to neutralize $\mathrm{H}_{2} \mathrm{SO}_{4}, \mathrm{HNO}_{3}$,

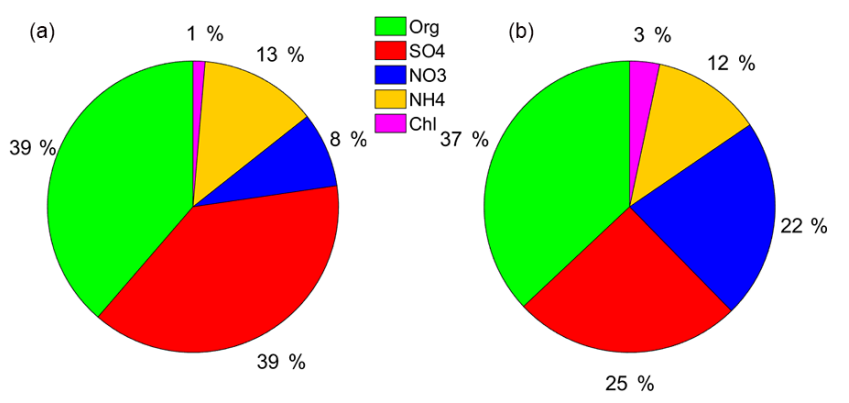

Figure 8. Aerosol mass fractions of $\mathrm{PM}_{1}$ measured by the ACSM for (a) Case I and (b) Case II.

and $\mathrm{HCl}$ in each case and that the dominant form of inorganics was $\mathrm{NH}_{4} \mathrm{NO}_{3}, \mathrm{NH}_{4} \mathrm{HSO}_{4}$, and $\left(\mathrm{NH}_{4}\right)_{2} \mathrm{SO}_{4}$. The acidity of aerosols in Case II is greater than that in Case I, suggesting that aerosols in Case II were more hygroscopic than those in Case I. This is consistent with the results presented in Sect. 3.2.1.

A hygroscopicity parameter, $\kappa$, was developed by Petters and Kreidenweis (2007). $\kappa$ can be calculated using the chemical composition information from Eq. (13) (Gysel et al., 2007; Y.-C. Liu et al., 2016; see Sect. 2.3.4). To further confirm the effect of aerosol hygroscopic growth on haze events, $\kappa$ is computed for each case based on the dominant form of the inorganics mentioned above.

Figure 8 shows the chemical species obtained from ground-based ACSM measurements of $\mathrm{PM}_{1}$ around the times of the cases. In Case I (Fig. 8a), $\mathrm{PM}_{1}$ was mainly made up of organic particles $(39 \%)$ and sulfate $(39 \%)$, followed by nitrate $(8 \%)$, ammonium $(13 \%)$, and chloride (1\%). In Case II (Fig. 8 b), $\mathrm{PM}_{1}$ was made up of $37 \%$ organics, $25 \%$ sulfate, $22 \%$ nitrate, $12 \%$ ammonium, and $1 \%$ chloride. Based on the aerosol-chemical-ion-pairing scheme introduced in Sect. 2.2.4 and the aerosol properties shown in Table 1, chloride and organics were neglected because of their relatively small contents and comparatively low hygroscopicities (Gysel et al., 2007; Petters and Kreidenweis, 2013). Table 4 lists the mass concentrations and volume fractions of $\mathrm{NH}_{4} \mathrm{NO}_{3}$, $\mathrm{NH}_{4} \mathrm{HSO}_{4}$, and $\left(\mathrm{NH}_{4}\right)_{2} \mathrm{SO}_{4}$ for each case as well as $\kappa$ computed using Eq. (13). The mass concentration of $\mathrm{H}_{2} \mathrm{SO}_{4}$ is equal to zero. Liu et al. (2014) have shown that $\kappa$ for $\mathrm{NH}_{4} \mathrm{NO}_{3}, \mathrm{NH}_{4} \mathrm{HSO}_{4}$, and $\left(\mathrm{NH}_{4}\right)_{2} \mathrm{SO}_{4}$ is equal to $0.68,0.56$, and 0.60 , respectively. The parameter $\kappa$ for Case I (0.557) is less than that for Case II (0.610). This suggests that the aerosol hygroscopicity for Case II was higher than that for Case I. It also suggests that, under the same ambient RH conditions, the nitrate content in aerosols can cause differences in the hygroscopicity of aerosols.

\subsubsection{Comparison with H-TDMA measurements}

In the last decade, many studies have compared remotely sensed and in situ aerosol-scattering enhancement factor 
Table 4. Calculated mass concentrations and volume fractions of $\mathrm{NH}_{4} \mathrm{NO}_{3}, \mathrm{NH}_{4} \mathrm{HSO}_{4}$, and $\left(\mathrm{NH}_{4}\right)_{2} \mathrm{SO}_{4}$, and the hygroscopicity parameter $(\kappa)$ for Case I and Case II.

\begin{tabular}{lrrr|rrr}
\hline & \multicolumn{3}{c|}{ Case I } & \multicolumn{3}{c}{ Case II } \\
\cline { 2 - 7 } & $\mathrm{NH}_{4} \mathrm{NO}_{3}$ & $\mathrm{NH}_{4} \mathrm{HSO}_{4}$ & $\left(\mathrm{NH}_{4}\right)_{2} \mathrm{SO}_{4}$ & $\mathrm{NH}_{4} \mathrm{NO}_{3}$ & $\mathrm{NH}_{4} \mathrm{HSO}_{4}$ & $\left(\mathrm{NH}_{4}\right)_{2} \mathrm{SO}_{4}$ \\
\hline Mass concentration $\left(\mu \mathrm{g} \mathrm{m}^{-3}\right)$ & 3.60 & 8.31 & 8.30 & 12.2979 & 10.3795 & 3.0616 \\
Volume fraction & 0.18 & 0.41 & 0.41 & 0.48 & 0.40 & 0.12 \\
\hline$\kappa$ & & 0.557 & & & 0.610 & \\
\hline
\end{tabular}

(a)

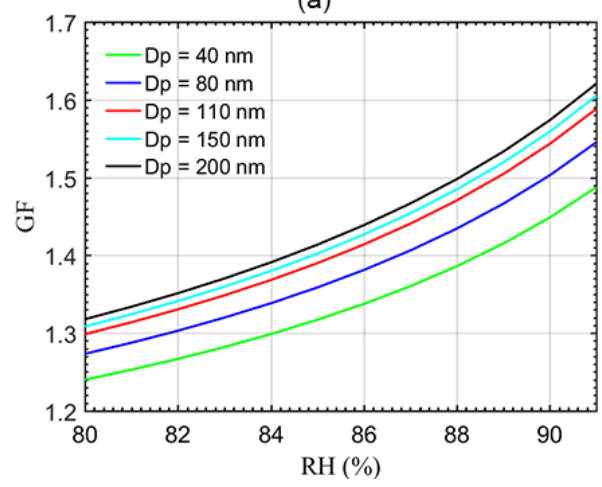

(b)

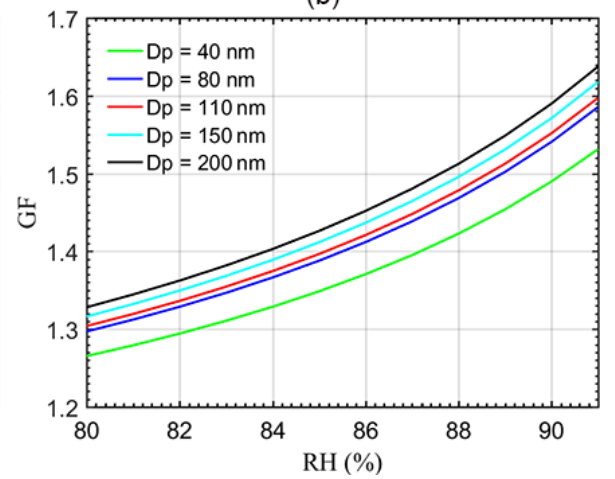

Figure 9. Aerosols size hygroscopic growth factor (GF) as a function of relative humidity (RH) for (a) Case I and (b) Case II. The different colors represent different particle sizes (Dp). These are the results of a model based on Eq. (3) from Gysel et al. (2009).

measurements using a humidified tandem nephelometer and have shown positive results (Zieger et al., 2011, 2012; Sheridan et al., 2012; Tesche et al., 2014; Lv et al., 2017). The H-TDMA is also a reliable instrument for measuring the aerosol diameter hygroscopicity due to water uptake (Liu et al., 1978). Aerosol GFs observed by the ground-based HTDMA at times nearest to the times of each case are examined next.

Based on H-TDMA-derived aerosol GFs at an RH level of $85 \%$ for different particle sizes $(40,80,110,150$, and $200 \mathrm{~nm}$ ), GFs for different aerosol sizes in both cases were extrapolated to different RH levels using Eq. (3) from Gysel et al. (2009), who used the $\kappa$ model introduced by Petters and Kreidenwies (2007). Figure 9 shows that Case II aerosol GFs at each RH level (80\%-91\%) are higher than those of Case I. Although the $f_{\beta}(\mathrm{RH})$ and GF are completely different parameters for calculating the hygroscopicity of aerosols and are difficult to compare quantitatively, the H-TDMA results offer a sense of confidence that aerosol hygroscopicity has an important influence on the formation of heavy haze.

In general, both the lidar-estimated aerosol backscattering hygroscopic enhancement factor and the ACSM and HTDMA measurements support the proposed hypothesis that the different hygroscopic properties of aerosols are mainly responsible for the strong coupling between the variability in $\mathrm{PM}_{1}$ and $\mathrm{PM}_{2.5}$ mass concentrations and the variability in $W$.

\section{Conclusions}

During late May 2016, the water vapor mixing ratio in the $0.3-4 \mathrm{~km}$ layer over Xingtai was generally less than $6 \mathrm{~g} \mathrm{~kg}^{-1}$ with a strong daily variability. Overall, the simultaneous temporal changes in the mass concentrations of $\mathrm{PM}_{1}$ and $\mathrm{PM}_{2.5}$ were strongly associated with that of the atmospheric water vapor content due to the hygroscopicity of aerosols. Two cases where this relationship was not seen were identified and further examined. Case I represents a relatively clean case, and Case II represents a polluted case. The lidarestimated aerosol backscattering coefficient hygroscopic enhancement factor $\left(f_{\beta}(\mathrm{RH})\right)$ for Case II is greater than that for Case I. The $\gamma$ and $b$ values from the Hänel and Kasten parameterizations, respectively, for Case II were larger than those for Case I. A key parameter affecting the hygroscopicity of aerosols, namely, the acid value (AV), was examined by comparing measured $\mathrm{NH}_{4}^{+}$and predicted $\mathrm{NH}_{4}^{+}$based on data obtained by the ACSM. The AV for Case I (1.35) was less than that for Case II (1.50) and the main form of inorganics was $\mathrm{NH}_{4} \mathrm{NO}_{3}, \mathrm{NH}_{4} \mathrm{HSO}_{4}$, and $\left(\mathrm{NH}_{4}\right)_{2} \mathrm{SO}_{4}$. The aerosol chemical composition determined by the ACSM showed that the aerosol hygroscopicity parameter $\kappa$ for Case II (0.610) was greater than that for Case I (0.577) due to the greater mass fraction of nitrate salt. Based on H-TDMA measurements, model results showed that the aerosol size hygroscopic growth factor (GF) in each particle size category (40, 
$80,110,150$, and $200 \mathrm{~nm}$ ) for Case II was greater than that for Case I.

The $f_{\beta}(\mathrm{RH}), \mathrm{GF}, \mathrm{AV}$, and $\kappa$ are completely different quantities for calculating the hygroscopicity of aerosols and are difficult to compare quantitatively. The lidar-estimated $f_{\beta}(\mathrm{RH})$ and ACSM and H-TDMA measurements show that the hygroscopic growth of aerosols has a strong influence on the process of air pollution. Under the same atmospheric relative humidity conditions, the stronger the hygroscopicity of aerosols, the more likely they are to cause severe air pollution. The mass fraction of the nitrate ion in aerosols was one of the main factors that determined the hygroscopic ability of aerosols in the study area (Xingtai). These findings not only reveal why haze events in Xintai can be severe, but they also provide scientific evidence that may be used to persuade the local government to prevent and control environmental contamination in this heavily polluted part of China.

Data availability. Data used in this study are available from the first author upon request (jchen@ mail.bnu.edu.cn).

Author contributions. ZL and JC determined the main goal of this study. JC carried it out, analyzed the data, and prepared the paper with contributions from all co-authors. YW provided technical guidance for related instruments.

Competing interests. The authors declare that they have no conflict of interest.

Special issue statement. This article is part of the special issue "Regional transport and transformation of air pollution in eastern China”. It is not associated with a conference.

Acknowledgements. This work was supported by the National Key R\&D Program of China (2017YFC1501702), the National Science Foundation of China (91544217), and the US National Science Foundation (AGS1534670 and AGS1837811).

Edited by: Yuan Wang

Reviewed by: two anonymous referees

\section{References}

Amil, N., Latif, M. T., Khan, M. F., and Mohamad, M.: Seasonal variability of $\mathrm{PM}_{2.5}$ composition and sources in the Klang Valley urban-industrial environment, Atmos. Chem. Phys., 16, 53575381, https://doi.org/10.5194/acp-16-5357-2016, 2016.

Anenberg, S. C., Horowitz, L. W., Tong, D. Q., and West, J. J.: An estimate of the global burden of anthropogenic ozone and fine particulate matter on premature human mortality using atmo- spheric modeling, Environ. Health Perspect., 118, 1189-1195, https://doi.org/10.1289/ehp.0901220, 2010.

Ångström, A.: The parameters of atmospheric turbidity, Tellus, 16, 64-75, https://doi.org/10.3402/tellusa.v16i1.8885, 1964.

Araujo, J. A., Barajas, B., Kleinman, M., Wang, X., Bennett, B. J., Gong, K. W., Navab, M., Harkema, J., Sioutas, C., Lusis, A. J., and Nel, A. E.: Ambient particulate pollutants in the ultrafine range promote early atherosclerosis and systemic oxidative stress, Circ. Res., 102, 589-596, https://doi.org/10.1161/CIRCRESAHA.107.164970, 2008.

Baars, H., Kanitz, T., Engelmann, R., Althausen, D., Heese, B., Komppula, M., Preißler, J., Tesche, M., Ansmann, A., Wandinger, U., Lim, J.-H., Ahn, J. Y., Stachlewska, I. S., Amiridis, V., Marinou, E., Seifert, P., Hofer, J., Skupin, A., Schneider, F., Bohlmann, S., Foth, A., Bley, S., Pfüller, A., Giannakaki, E., Lihavainen, H., Viisanen, Y., Hooda, R. K., Pereira, S. N., Bortoli, D., Wagner, F., Mattis, I., Janicka, L., Markowicz, K. M., Achtert, P., Artaxo, P., Pauliquevis, T., Souza, R. A. F., Sharma, V. P., van Zyl, P. G., Beukes, J. P., Sun, J., Rohwer, E. G., Deng, R., Mamouri, R.-E., and Zamorano, F.: An overview of the first decade of PollyNET: an emerging network of automated Raman-polarization lidars for continuous aerosol profiling, Atmos. Chem. Phys., 16, 5111-5137, https://doi.org/10.5194/acp16-5111-2016, 2016.

Bedoya-Velásquez, A. E., Navas-Guzmán, F., Granados-Muñoz, M. J., Titos, G., Román, R., Casquero-Vera, J. A., Ortiz-Amezcua, P., Benavent-Oltra, J. A., de Arruda Moreira, G., MontillaRosero, E., Hoyos, C. D., Artiñano, B., Coz, E., Olmo-Reyes, F. J., Alados-Arboledas, L., and Guerrero-Rascado, J. L.: Hygroscopic growth study in the framework of EARLINET during the SLOPE I campaign: synergy of remote sensing and in situ instrumentation, Atmos. Chem. Phys., 18, 7001-7017, https://doi.org/10.5194/acp-18-7001-2018, 2018.

Bucholtz, A.: Rayleigh-scattering calculations for the terrestrial atmosphere, Appl. Opt., 34, 2765, https://doi.org/10.1364/AO.34.002765, 1995.

Carrico, C. M.: Mixtures of pollution, dust, sea salt, and volcanic aerosol during ACE-Asia: Radiative properties as a function of relative humidity, J. Geophys. Res., 108, 8650, https://doi.org/10.1029/2003JD003405, 2003.

Carrico, C. M., Petters, M. D., Kreidenweis, S. M., Sullivan, A. P., McMeeking, G. R., Levin, E. J. T., Engling, G., Malm, W. C., and Collett Jr., J. L.: Water uptake and chemical composition of fresh aerosols generated in open burning of biomass, Atmos. Chem. Phys., 10, 5165-5178, https://doi.org/10.5194/acp10-5165-2010, 2010.

Chen, J., Zhao, C. S., Ma, N., and Yan, P.: Aerosol hygroscopicity parameter derived from the light scattering enhancement factor measurements in the North China Plain, Atmos. Chem. Phys., 14, 8105-8118, https://doi.org/10.5194/acp-14-8105-2014, 2014.

Chen, W.-N., Chiang, C.-W., and Nee, J.-B.: Lidar ratio and depolarization ratio for cirrus clouds, Appl. Opt., 41, 6470-6476, https://doi.org/10.1364/AO.41.006470, 2002.

Covert, D. S., Charlson, R. J., and Ahlquist, N. C.: A study of the relationship of chemical composition and humidity to light scattering by aerosols, J. Appl. Meteorol., 11, 968-976, https://doi.org/10.1175/15200450(1972)011<0968:ASOTRO>2.0.CO;2, 1972. 
Di Girolamo, P., Summa, D., Bhawar, R., Di Iorio, T., Cacciani, M., Veselovskii, I., Dubovik, O., and Kolgotin, A.: Raman lidar observations of a Saharan dust outbreak event: characterization of the dust optical properties and determination of particle size and microphysical parameters, Atmos. Environ., 50, 66-78, https://doi.org/10.1016/j.atmosenv.2011.12.061, 2012.

Feingold, G. and Morley, B.: Aerosol hygroscopic properties as measured by lidar and comparison with in situ measurements, J. Geophys. Res., 108, 4327, https://doi.org/10.1029/2002JD002842, 2003.

Fernald, F. G.: Analysis of atmospheric lidar observations: some comments, Appl. Opt., 23, 652-653, https://doi.org/10.1364/AO.23.000652, 1984.

Fernald, F. G., Herman, B. M., and Reagan, J. A.: Determination of Aerosol Height Distributions by Lidar, J. Appl. Meteorol., 11, 482-489, https://doi.org/10.1175/15200450(1972)011<0482:DOAHDB>2.0.CO;2, 1972.

Fernández, A. J., Apituley, A., Veselovskii, I., Suvorina, A., Henzing, J., Pujadas, M., and Artínano, B.: Study of aerosol hygroscopic events over the Cabauw experimental site for atmospheric research (CESAR) using the multiwavelength Raman lidar Caeli, Atmos. Environ., 120, 484-498, https://doi.org/10.1016/j.atmosenv.2015.08.079, 2015.

Fountoukis, C. and Nenes, A.: ISORROPIA II: a computationally efficient thermodynamic equilibrium model for $\mathrm{K}^{+}$. $\mathrm{Ca}^{2+}-\mathrm{Mg}^{2+}-\mathrm{NH}_{4}^{+}-\mathrm{Na}^{+}-\mathrm{SO}_{4}^{2-}-\mathrm{NO}_{3}^{-}-\mathrm{Cl}^{-}-\mathrm{H}_{2} \mathrm{O}$ aerosols, Atmos. Chem. Phys., 7, 4639-4659, https://doi.org/10.5194/acp-74639-2007, 2007.

Froidevaux, M., Higgins, C. W., Simeonov, V., Ristori, P., Pardyjak, E., Serikov, I., Calhoun, R., Bergh, H. van den, and Parlange, M. B.: A Raman lidar to measure water vapor in the atmospheric boundary layer, Adv. Water Resour., 51, 354-356, https://doi.org/10.1016/j.advwatres.2012.04.008, 2013.

Fu, X., Guo, H., Wang, X., Ding, X., He, Q., Liu, T., and Zhang, Z.: $\mathrm{PM}_{2.5}$ acidity at a background site in the Pearl River Delta region in fall-winter of 2007-2012, J. Hazard. Mater., 286, 484492, https://doi.org/10.1016/j.jhazmat.2015.01.022, 2015.

Gassó, S., Hegg, D. A., Covert, D. S., Collins, D., Noone, K. J., Öström, E., Schmid, B., Russell, P. B., Livingston, J. M., Durkee, P. A., and Jonsson, H.: Influence of humidity on the aerosol scattering coefficient and its effect on the upwelling radiance during ACE-2, Tellus B, 52, 546-567, https://doi.org/10.3402/tellusb.v52i2.16657, 2000.

Granados-Muñoz, M. J., Navas-Guzmán, F., Bravo-Aranda, J. A., Guerrero-Rascado, J. L., Lyamani, H., Valenzuela, A., Titos, G., Fernández-Gálvez, J., and Alados-Arboledas, L.: Hygroscopic growth of atmospheric aerosol particles based on active remote sensing and radiosounding measurements: selected cases in southeastern Spain, Atmos. Meas. Tech., 8, 705-718, https://doi.org/10.5194/amt-8-705-2015, 2015.

Gysel, M., Crosier, J., Topping, D. O., Whitehead, J. D., Bower, K. N., Cubison, M. J., Williams, P. I., Flynn, M. J., McFiggans, G. B., and Coe, H.: Closure study between chemical composition and hygroscopic growth of aerosol particles during TORCH2, Atmos. Chem. Phys., 7, 6131-6144, https://doi.org/10.5194/acp7-6131-2007, 2007.

Gysel, M., McFiggans, G. B., and Coe, H.: Inversion of tandem differential mobility analyser
(TDMA) measurements, J. Aerosol Sci., 40, 134-151, https://doi.org/10.1016/j.jaerosci.2008.07.013, 2009.

Hänel, G.: The properties of atmospheric aerosol particles as functions of the relative humidity at thermodynamic equilibrium with the surrounding moist air, Adv. Geophys., 19, 73-188, https://doi.org/10.1016/S0065-2687(08)60142-9, 1976.

Hänel G.: An attempt to interpret the humidity dependencies of the aerosol extinction and scattering coefficients, Atmos. Environ., 15, 403-406, https://doi.org/10.1016/0004-6981(78)901920,1980 .

Hu Y., Lin J., Zhang S., Kong L., Fu H., and Chen J.: Identification of the typical metal particles among haze, fog, and clear episodes in the Beijing atmosphere, Sci. Total Environ., 511, 369-380, https://doi.org/10.1016/j.scitotenv.2014.12.071, 2015.

Huang, R., Zhang, Y., Bozzetti, C., Ho, K., Cao, J., Han, Y., Daellenbach, K. R., Slowik, J. G., Platt, S. M., Canonaco, F., Zotter, P., Wolf, R., Pieber, S. M., Bruns, E. A., Crippa, M., Ciarelli, G., Piazzalunga, A., Schwikowski, M., Abbaszade, G., SchnelleKreis, J., Zimmermann, R., An, Z., Szidat, S., Baltensperger, U., Haddad, I. E., and Prévôt, A. S. H.: High secondary aerosol contribution to particulate pollution during haze events in China, Nature, 514, 218-222, https://doi.org/10.1038/nature13774, 2014.

IPCC: Climate Change 2013 - The Physical Science Basis, Contrib. Work. Gr. I to Fifth Assess. Rep. Intergov. Panel Clim. Chang., https://doi.org/10.1038/446727a, 2013

Jeong, M. J., Li, Z., Andrews, E., and Tsay, S. C.: Effect of aerosol humidification on the column aerosol optical thickness over the Atmospheric Radiation Measurement Southern Great Plains site, J. Geophys. Res.-Atmos., 112, D10202, https://doi.org/10.1029/2006JD007176, 2007.

Koloutsou-Vakakis, S., Carrico, C. M., Kus, P., Rood, M. J., Li, Z., Shrestha, R., Ogren, J. A., Chow, J. C., and Watson, J. G.: Aerosol properties at a mid-latitude Northern Hemisphere continental site, J. Geophys. Res.-Atmos., 106, 3019-3032, https://doi.org/10.1029/2000JD900126, 2001.

Kotchenruther, R. A., Hobbs, P. V., and Hegg, D. A.: Humidification factors for atmospheric aerosols off the mid-Atlantic coast of the United States, J. Geophys. Res.-Atmos., 104, 2239-2251, https://doi.org/10.1029/98JD01751, 1998.

Kusumaningtyas, S. D. A. and Aldrian, E.: Impact of the June 2013 Riau province Sumatera smoke haze event on regional air pollution, Environ. Res. Lett., 11, 7, https://doi.org/10.1088/17489326/11/7/075007, 2016.

Leblanc, T., McDermid, I. S., and Walsh, T. D.: Ground-based water vapor raman lidar measurements up to the upper troposphere and lower stratosphere for long-term monitoring, Atmos. Meas. Tech., 5, 17-36, https://doi.org/10.5194/amt-5-17-2012, 2012.

Li, Z., Guo, J., Ding, A., Liao, H., Liu, J., Sun, Y., Wang, T., Xue, H., Zhang, H., and Zhu, B.: Aerosol and boundary-layer interactions and impact on air quality, Natl. Sci. Rev., 4, 810-833, https://doi.org/10.1093/nsr/nwx117, 2017.

Liao, H., Chang, W., and Yang, Y.: Climatic effects of air pollutants over china: a review, Adv. Atmos. Sci., 32, 115-139, https://doi.org/10.1007/s00376-014-0013-x, 2015.

Liu, B. Y. H., Pui, D. Y. H., Whitby, K. T., Kittelson, D. B., Kousaka, Y., and McKenzie, R. L.: The aerosol mobility chromatograph: a new detector for sulfuric acid aerosols, Atmos. Environ., 12, 99 104, https://doi.org/10.1016/0004-6981(78)90192-0, 1978. 
Liu, H. J., Zhao, C. S., Nekat, B., Ma, N., Wiedensohler, A., van Pinxteren, D., Spindler, G., Müller, K., and Herrmann, H.: Aerosol hygroscopicity derived from size-segregated chemical composition and its parameterization in the North China Plain, Atmos. Chem. Phys., 14, 2525-2539, https://doi.org/10.5194/acp-14-2525-2014, 2014.

Liu, Q., Ma, T., Olson, M. R., Liu, Y., Zhang, T., Wu, Y., and Schauer, J. J.: Temporal variations of black carbon during haze and non-haze days in Beijing, Sci. Rep., 6, 33331, https://doi.org/10.1038/srep33331, 2016.

Liu, X. G., Li, J., Qu, Y., Han, T., Hou, L., Gu, J., Chen, C., Yang, Y., Liu, X., Yang, T., Zhang, Y., Tian, H., and Hu, M.: Formation and evolution mechanism of regional haze: a case study in the megacity Beijing, China, Atmos. Chem. Phys., 13, 4501-4514, https://doi.org/10.5194/acp-13-4501-2013, 2013.

Liu, Y.-C., Wu, Z. J., Tan, T. Y., Wang, Y. J., Qin, Y. H., Zheng, J., Li, M. R., and Hu, M.: Estimation of the $\mathrm{PM}_{2.5}$ effective hygroscopic parameter and water content based on particle chemical composition: methodology and case study, Sci. China Earth Sci., 59, 1683-1691, https://doi.org/10.1007/s11430-016-53139, 2016.

Lv, M., Liu, D., Li, Z., Mao, J., Sun, Y., Wang, Z., Wang, Y., and Xie, C.: Hygroscopic growth of atmospheric aerosol particles based on lidar, radiosonde, and in situ measurements: case studies from the Xinzhou field campaign, J. Quant. Spectrosc. Ra., 188, 60-70, https://doi.org/10.1016/j.jqsrt.2015.12.029, 2017.

MacKinnon, D. J.: The effect of hygroscopic particles on the backscattered power from a laser beam, Atmos. Sci., 26, 500-510, https://doi.org/10.1175/15200469(1969)026<0500:TEOHPO>2.0.CO;2, 1969.

Melfi, S. H.: Remote measurements of the atmosphere using Raman scattering, Appl. Opt., 11, 1605-1610, https://doi.org/10.1364/AO.11.001605, 1972.

Ng, N. L., Herndon, S. C., Trimborn, A., Canagaratna, M. R., Croteau, P. L., Onasch, T. B., Sueper, D., Worsnop, D. R., Zhang, Q., Sun, Y. L., and Jayne, J. T.: An Aerosol Chemical Speciation Monitor (ACSM) for routine monitoring of the composition and mass concentrations of ambient aerosol, Aerosol Sci. Technol., 45, 780-794, https://doi.org/10.1080/02786826.2011.560211, 2011.

Pahlow, M., Feingold, G., Jefferson, A., Andrews, E., Ogren, J. A., Wang, J., Lee, Y. N., Ferrare, R. A., and Turner, D. D.: Comparison between lidar and nephelometer measurements of aerosol hygroscopicity at the Southern Great Plains Atmospheric Radiation Measurement site, J. Geophys. Res.-Atmos., 111, D05S15, https://doi.org/10.1029/2004JD005646, 2006.

Pan, X. L., Yan, P., Tang, J., Ma, J. Z., Wang, Z. F., Gbaguidi, A., and Sun, Y. L.: Observational study of influence of aerosol hygroscopic growth on scattering coefficient over rural area near Beijing mega-city, Atmos. Chem. Phys., 9, 7519-7530, https://doi.org/10.5194/acp-9-7519-2009, 2009.

Petters, M. D. and Kreidenweis, S. M.: A single parameter representation of hygroscopic growth and cloud condensation nucleus activity, Atmos. Chem. Phys., 7, 1961-1971, https://doi.org/10.5194/acp-7-1961-2007, 2007.

Petters, M. D. and Kreidenweis, S. M.: A single parameter representation of hygroscopic growth and cloud condensation nucleus activity - Part 3: Including surfactant partitioning, At- mos. Chem. Phys., 13, 1081-1091, https://doi.org/10.5194/acp13-1081-2013, 2013.

Qu, W., Wang, J., Zhang, X., Wang, Y., Gao, S., Zhao, C., Sun, L., Zhou, Y., Wang, W., Liu, X., Hu, H., and Huang, F.: Effect of weakened diurnal evolution of atmospheric boundary layer to air pollution over eastern China associated to aerosol, cloud-ABL feedback, Atmos. Environ., 185, 168-179, https://doi.org/10.1016/j.atmosenv.2018.05.014, 2018.

Quan, J., Zhang, Q., He, H., Liu, J., Huang, M., and Jin, H.: Analysis of the formation of fog and haze in North China Plain (NCP), Atmos. Chem. Phys., 11, 8205-8214, https://doi.org/10.5194/acp-11-8205-2011, 2011.

Quan, J., Gao, Y., Zhang, Q., Tie, X., Cao, J., Han, S., Meng, J., Chen, P., and Zhao, D.: Evolution of planetary boundary layer under different weather conditions, and its impact on aerosol concentrations, Particuology, 11, 34-40, https://doi.org/10.1016/j.partic.2012.04.005, 2013.

Reilly, P. J. and Wood, R. H.: The prediction of the properties of mixed electrolytes from measurements on common ion mixtures, J. Phys. Chem., 73, 4292-4297, https://doi.org/10.1021/j100846a043, 1969.

Rosati, B., Wehrle, G., Gysel, M., Zieger, P., Baltensperger, U., and Weingartner, E.: The white-light humidified optical particle spectrometer (WHOPS) - a novel airborne system to characterize aerosol hygroscopicity, Atmos. Meas. Tech., 8, 921-939, https://doi.org/10.5194/amt-8-921-2015, 2015.

Sheridan, P. J., Andrews, E., Ogren, J. A., Tackett, J. L., and Winker, D. M.: Vertical profiles of aerosol optical properties over central Illinois and comparison with surface and satellite measurements, Atmos. Chem. Phys., 12, 11695-11721, https://doi.org/10.5194/acp-12-11695-2012, 2012.

Sherlock, V., Hauchecorne, A., and Lenoble, J.: Methodology for the independent calibration of Raman backscatter water-vapor lidar systems, Appl. Opt., 38, 5816-5837, https://doi.org/10.1364/AO.38.005816, 1999.

Shi, H., Wang, Y., Chen, J., and Huisingh, D.: Preventing smog crises in China and globally, J. Clean. Prod., 112, 1261-1271, https://doi.org/10.1016/j.jclepro.2015.10.068, 2016.

Sorooshian, A., Hersey, S., Brechtel, F. J., Corless, A., Flagan, R. C., and Seinfeld, J. H.: Rapid, size-resolved aerosol hygroscopic growth measurements: differential aerosol sizing and hygroscopicity spectrometer probe (DASH-SP), Aerosol Sci. Technol., 42, 445-464, https://doi.org/10.1080/02786820802178506, 2008.

Stokes, R. H. and Robinson, R. A.: Interactions in aqueous nonelectrolyte solutions. I. Solute-solvent equilibria, J. Phys. Chem., 70, 2126-2131, https://doi.org/10.1021/j100879a010, 1966.

Stolzenburg, M. R. and McMurry, P. H.: Equations governing single and tandem DMA configurations and a new lognormal approximation to the transfer function, Aerosol Sci. Tech., 42, 421-432, https://doi.org/10.1080/02786820802157823, 2008.

Strutt, J. W.: XV, On the light from the sky, its polarization and colour, London, Edinburgh, Dublin Philos. Mag. J. Sci., 41, 107120, https://doi.org/10.1080/14786447108640452, 1871.

Su, T., Li, J., Li, J., Li, C., Chu, Y., Zhao, Y., Guo, J., Yu, Y., and Wang, L.: The evolution of springtime water vapor over Beijing observed by a high dynamic Raman lidar system: case studies, IEEE J. Sel. Top. Appl. Earth Obs. Remote Sens., 10, 17151726, https://doi.org/10.1109/JSTARS.2017.2653811, 2017. 
Su, T., Li, Z., and Kahn, R.: Relationships between the planetary boundary layer height and surface pollutants derived from lidar observations over China: regional pattern and influencing factors, Atmos. Chem. Phys., 18, 15921-15935, https://doi.org/10.5194/acp-18-15921-2018, 2018.

Sun, J., Zhang, Q., Canagaratna, M. R., Zhang, Y., Ng, N. L., Sun, Y., Jayne, J. T., Zhang, X., Zhang, X., and Worsnop, D. R.: Highly time- and size-resolved characterization of submicron aerosol particles in Beijing using an Aerodyne Aerosol Mass Spectrometer, Atmos. Environ., 44, 131-140, https://doi.org/10.1016/j.atmosenv.2009.03.020, 2009.

Sun, Y., Zhuang, G., Tang, A., Wang, Y., and An, Z.: Chemical characteristics of $\mathrm{PM}_{2.5}$ and $\mathrm{PM}_{10}$ in haze-fog episodes in Beijing, Environ. Sci. Technol., 40, 3148-3155, https://doi.org/10.1021/es051533g, 2006.

Swietlicki, E., Hansson, H. C., Hämeri, K., Svenningsson, B., Massling, A., Mcfiggans, G., Mcmurry, P. H., Petäjä, T., Tunved, P., Gysel, M., Topping, D., Weingartner, E., Baltensperger, U., Rissler, J., Wiedensohler, A., and Kulmala, M.: Hygroscopic properties of submicrometer atmospheric aerosol particles measured with H-TDMA instruments in various environments - a review, Tellus B, 60, 432-469, https://doi.org/10.1111/j.16000889.2008.00350.x, 2008.

Tan H., Xu H., Wan Q., Li F., Deng X., Chan P. W., Xia D., and Yin Y.: Design and application of an unattended multifunctional H-TDMA system, J. Atmos. Ocean Tech., 30, 1136-1148, https://doi.org/10.1175/JTECH-D-12-00129.1, 2013.

Tang, I. N. and Munkelwitz, H. R.: Water activities, densities, and refractive indices of aqueous sulfates and sodium nitrate droplets of atmospheric importance, J. Geophys. Res., 99, 18801-18808, https://doi.org/10.1029/94JD01345, 1994.

Tardif, R.: Boundary layer aerosol backscattering and its relationship to relative humidity from a combined Raman-elastic backscatter lidar, Class Project for ATOC 5235 Remote Sensing of the Atmosphere and Oceanic, University of Colorado, Colorado, 2002.

Tesche, M., Zieger, P., Rastak, N., Charlson, R. J., Glantz, P., Tunved, P., and Hansson, H.-C.: Reconciling aerosol light extinction measurements from spaceborne lidar observations and in situ measurements in the Arctic, Atmos. Chem. Phys., 14, 78697882, https://doi.org/10.5194/acp-14-7869-2014, 2014.

Tie, X., Zhang, Q., He, H., Cao, J., Han, S., Gao, Y., Li, X., and Jia, X. C.: A budget analysis of the formation of haze in Beijing, Atmos. Environ., 100, 25-36, https://doi.org/10.1016/j.atmosenv.2014.10.038, 2015.

Titos, G., Cazorla, A., Zieger, P., Andrews, E., Lyamani, H., Granados-Muñoz, M. J., Olmo, F. J., and AladosArboledas, L.: Erratum to 'Effect of hygroscopic growth on the aerosol light-scattering coefficient: A review of measurements, techniques and error sources' [Atmos. Environ. 141C (2016) 494-507] (S1352231016305404) (https://doi.org/10.1016/j.atmosenv.2016.07.021)), Atmos. Environ., https://doi.org/10.1016/j.atmosenv.2018.02.030, 2018.

Tiwari, S., Tiwari, S., Hopke, P. K., Attri, S. D., Soni, V. K., and Singh, A. K.: Variability in optical properties of atmospheric aerosols and their frequency distribution over a mega city “New Delhi," India, Environ. Sci. Pollut. Res., 23, 8781-8793, https://doi.org/10.1007/s11356-016-6060-3, 2016.
Tobin, I., Bony, S., and Roca, R.: Observational evidence for relationships between the degree of aggregation of deep convection, water vapor, surface fluxes, and radiation, J. Climate, 25, 68856904, https://doi.org/10.1175/JCLI-D-11-00258.1, 2012.

Veselovskii, I., Whiteman, D. N., Kolgotin, A., Andrews, E., and Korenskii, M.: Demonstration of aerosol property profiling by multi-wavelength lidar under varying relative humidity conditions, J. Atmos. Ocean. Tech., 26, 1543-1557, https://doi.org/10.1175/2009JTECHA1254.1, 2009.

Wang, W., Gong, W., Mao, F., and Zhang, J.: Long-term measurement for low-tropospheric water vapor and aerosol by Raman lidar in Wuhan, Atmosphere (Basel), 6, 521-533, https://doi.org/10.3390/atmos6040521, 2015.

Wang, Y.-F., Hua, D., Wang, L., Tang, J., Mao, J., and Kobayashi, T.: Observations and analysis of relationship between water vapor and aerosols by using Raman lidar, Jpn. J. Appl. Phys., 51, 10R, https://doi.org/10.1143/JJAP.51.102401, 2012.

Wang, Y. -F., Zhang, J., Fu, Q., Song, Y., Di, H., Li, B., and Hua, D.: Variations in the water vapor distribution and the associated effects on fog and haze events over Xi' an based on Raman lidar data and back trajectories, Appl. Opt., 56, 7927-7938, https://doi.org/10.1364/AO.56.007927, 2017.

Wang, Y. S., Yao, L., Wang, L. L., Liu, Z. R., Ji, D. S., Tang, G. Q., Zhang, J. K., Sun, Y., Hu, B., and Xin, J. Y.: Mechanism for the formation of the January 2013 heavy haze pollution episode over central and eastern China, Sci. China Earth Sci., 57, 14-25, https://doi.org/10.1007/s11430-013-4773-4, 2014.

Wang, Y., Zhang, F., Li, Z., Tan, H., Xu, H., Ren, J., Zhao, J., Du, W., and Sun, Y.: Enhanced hydrophobicity and volatility of submicron aerosols under severe emission control conditions in Beijing, Atmos. Chem. Phys., 17, 5239-5251, https://doi.org/10.5194/acp-17-5239-2017, 2017.

Wang, Y., Li, Z., Zhang, Y., Du, W., Zhang, F., Tan, H., Xu, H., Fan, T., Jin, X., Fan, X., Dong, Z., Wang, Q., and Sun, Y.: Characterization of aerosol hygroscopicity, mixing state, and $\mathrm{CCN}$ activity at a suburban site in the central North China Plain, Atmos. Chem. Phys., 18, 11739-11752, https://doi.org/10.5194/acp-18-117392018, 2018.

Watson, J. G.: Visibility: science and regulation, J. Air Waste Manag. Assoc., 52, 628-713, https://doi.org/10.1080/10473289.2002.10470813, 2002.

Yan, X., Shi, W., Li, Z., Li, Z., Luo, N., Zhao, W., Wang, H. and Yu, X.: Satellite-based $\mathrm{PM}_{2.5}$ estimation using fine-mode aerosol optical thickness over China, Atmos. Environ., 170, 290-302, https://doi.org/10.1016/j.atmosenv.2017.09.023, 2017.

Yang, Y. R., Liu, X. G., Qu, Y., An, J. L., Jiang, R., Zhang, Y. H., Sun, Y. L., Wu, Z. J., Zhang, F., Xu, W. Q., and Ma, Q. X.: Characteristics and formation mechanism of continuous hazes in China: a case study during the autumn of 2014 in the North China Plain, Atmos. Chem. Phys., 15, 8165-8178, https://doi.org/10.5194/acp-15-8165-2015, 2015.

Zdanovskii, A. B.: New methods for calculating solubilities of electrolytes in multi-component systems, Zhur. Fiz. Khim., 22, 1475-1485, 1948.

Zhang, L., Sun, J. Y., Shen, X. J., Zhang, Y. M., Che, H., Ma, Q. L., Zhang, Y. W., Zhang, X. Y., and Ogren, J. A.: Observations of relative humidity effects on aerosol light scattering in the Yangtze River Delta of China, Atmos. Chem. Phys., 15, 84398454, https://doi.org/10.5194/acp-15-8439-2015, 2015. 
Zhang, Q., Jimenez, J. L., Worsnop, D. R., and Canagaratna, M.: A case study of urban particle acidity and its influence on secondary organic aerosol, Environ. Sci. Technol., 41, 3213-3219, https://doi.org/10.1021/es061812j, 2007.

Zhang, Q. H., Zhang, J. P., and Xue, H. W.: The challenge of improving visibility in Beijing, Atmos. Chem. Phys., 10, 78217827, https://doi.org/10.5194/acp-10-7821-2010, 2010.

Zhang, Y., Du, W., Wang, Y., Wang, Q., Wang, H., Zheng, H., Zhang, F., Shi, H., Bian, Y., Han, Y., Fu, P., Canonaco, F., Prévôt, A. S. H., Zhu, T., Wang, P., Li, Z., and Sun, Y.: Aerosol chemistry and particle growth events at an urban downwind site in North China Plain, Atmos. Chem. Phys., 18, 14637-14651, https://doi.org/10.5194/acp-18-14637-2018, 2018.

Zieger, P., Weingartner, E., Henzing, J., Moerman, M., de Leeuw, G., Mikkilä, J., Ehn, M., Petäjä, T., Clémer, K., van Roozendael, M., Yilmaz, S., Frieß, U., Irie, H., Wagner, T., Shaiganfar, R., Beirle, S., Apituley, A., Wilson, K., and Baltensperger, U.: Comparison of ambient aerosol extinction coefficients obtained from in-situ, MAX-DOAS and LIDAR measurements at Cabauw, Atmos. Chem. Phys., 11, 2603-2624, https://doi.org/10.5194/acp11-2603-2011, 2011.
Zieger, P., Kienast-Sjögren, E., Starace, M., von Bismarck, J., Bukowiecki, N., Baltensperger, U., Wienhold, F. G., Peter, T., Ruhtz, T., Collaud Coen, M., Vuilleumier, L., Maier, O., Emili, E., Popp, C., and Weingartner, E.: Spatial variation of aerosol optical properties around the high-alpine site Jungfraujoch (3580 ma.s.1.), Atmos. Chem. Phys., 12, 7231-7249, https://doi.org/10.5194/acp-12-7231-2012, 2012.

Zieger, P., Fierz-Schmidhauser, R., Poulain, L., Müller, T., Birmili, W., Spindler, G., Wiedensohler, A., Baltensperger, U., and Weingartner, E.: Influence of water uptake on the aerosol particle light scattering coefficients of the Central European aerosol, Tellus B, 66, 22716, https://doi.org/10.3402/tellusb.v66.22716, 2014.

Zou, J., Liu, Z., Hu, B., Huang, X., Wen, T., Ji, D., Liu, J., Yang, Y., Yao, Q., and Wang, Y.: Aerosol chemical compositions in the North China Plain and the impact on the visibility in Beijing and Tianjin, Atmos. Res., 201, 235-246, https://doi.org/10.1016/j.atmosres.2017.09.014, 2018. 